\title{
$3-2018$
}

\section{The role of financial analysts in stock market efficiency with respect to annual earnings and its cash and accrual components}

Dana Hollie

Philip B. Shane

College of William and Mary, Phil.Shane@mason.wm.edu

Qiuhong Zhao

\section{Recommended Citation}

Hollie, Dana; Shane, Philip B.; and Zhao, Qiuhong, The role of financial analysts in stock market efficiency with respect to annual earnings and its cash and accrual components (2018). ACCOUNTING AND FINANCE, 57(1).

10.1111/acfi. 12138

This Article is brought to you for free and open access by the Arts and Sciences at W\&M ScholarWorks. It has been accepted for inclusion in Arts \& Sciences Articles by an authorized administrator of W\&M ScholarWorks. For more information, please contact scholarworks@wm.edu. 


\title{
The role of financial analysts in stock market efficiency with respect to annual earnings and its cash and accrual components
}

\author{
Dana Hollie ${ }^{\mathrm{a}}$, Philip B. Shane ${ }^{\mathrm{b}}$ and Qiuhong Zhao ${ }^{\mathrm{c}}$ \\ ${ }^{\text {a }}$ E. J. Ourso College of Business, Louisiana State University, Baton Rouge, LA, USA \\ ${ }^{\mathrm{b}}$ Mason School of Business, College of William and Mary, Williamsburg, VA, USA \\ ${ }^{\mathrm{C}}$ College of Business, University of Missouri, Columbia, MO, USA
}

\begin{abstract}
This study examines biases in stock prices and financial analysts' earnings forecasts. These biases take the form of systematic overweighting or underweighting of the persistence characteristics of cash versus accrual earnings components. Our evidence suggests that stock prices tend to overweight and financial analysts tend to underweight these persistence characteristics. Furthermore, we find that analysts' underweighting attenuates stock price overweighting. However, we find little evidence that the overweighting in stock prices attenuates analyst underweighting. This study brings a new perspective to the literature regarding the disciplining role of financial analysts in capital markets.
\end{abstract}

Key words: Accrual; Analyst forecast; Forecasting bias; Free cash flow; Market efficiency

JEL classification: G14, M41

doi: $10.1111 /$ acfi. 12138

We thank I/B/E/S for providing the analyst forecast data for this study. For their helpful comments, we thank Sudipta Basu, Katherine Gunny, Steve Rock and seminar participants at the 2015 European Accounting Association Annual Congress, Bond University, College of William and Mary, Colorado State University, Florida Atlantic University, George Mason University, Louisiana State University, Monash University, and the Universities of Auckland, Colorado, Hawaii, North Carolina at Charlotte, and Queensland. Shane gratefully acknowledges financial support from the Norfolk Southern Accounting Faculty Research Fund at the College of William and Mary.

Received 26 March 2014; accepted 1 April 2015 by Steven Cahan (Editor in Chief). 


\section{Introduction}

This study investigates the role of financial analysts in stock market efficiency with respect to earnings information derived from corporate annual reports to shareholders. ${ }^{1}$ Sloan (1996) finds that the market overweights (underweights) the persistence characteristics of accrual (cash flow) components of earnings, where persistence is estimated with reference to the coefficient relating each current-year earnings component to the whole of next year's net operating income. ${ }^{2}$ Mashruwala et al. (2006) report that the cash-flow and accrual anomalies are concentrated in stocks with low trading volume and other characteristics associated with high arbitrage costs. As stocks covered by financial analysts tend to have relatively high trading volume (Alford and Berger, 1999; Frankel et al., 2006), we consider it unlikely that financial analyst activity drives the anomalous stock price behaviour discovered by Sloan. Our study focuses on whether financial analysts play a role in mitigating the accrual anomaly in the stocks they follow.

Ahmed et al. (2006) also study analyst behaviour in relation to the accrual and cash-flow anomalies. That study disaggregates total earnings into operating cash flow, long-term accruals and current accruals. The study finds strong evidence of consensus analyst forecast underweighting of persistence of operating cash flows and long-term accruals, and moderate overweighting of the persistence of current accruals; that is, the results suggest that the underweighting of persistence characteristics of long-term accruals (operating cash flow) is about 2.8 (2.9) times the overweighting of the persistence of current accruals. The net underweighting of the persistence of total accruals is statistically significant. Our study investigates whether the analyst underweighting of total accruals persistence observed by Ahmed et al. (2006) mitigates market overweighting of accruals persistence observed by Sloan (1996) and many subsequent studies. ${ }^{3}$ We also investigate whether analyst underweighting offsets what otherwise might be market overweighting of the persistence of the cash component of annual earnings.

\footnotetext{
${ }^{1}$ See Schipper (1991), Brown (1993) and Ramnath et al. (2008a,b) for extensive reviews of the literature investigating the role of financial analysts in capital markets.

${ }^{2}$ See Collins and Hribar (2000) for a similar result in the context of quarterly accrual and cash earnings.

${ }^{3}$ Like Ahmed et al. (2006), Drake and Myers (2011) find that analysts overweight the persistence of current accruals. Drake and Myers proceed with an investigation of whether differences in this overweighting across individual analysts depend on analyst characteristics such as experience, access to resources and portfolio complexity. Drake and Myers do not assess analyst reaction to total accruals or to the components studied in our study. Our study differs from Drake and Myers in other important ways discussed in Section 5.
} 
Prior research provides evidence that stock prices respond, at least partially, to analysts' earnings forecast revisions (Gleason and Lee, 2003), and analysts respond, at least partially, to information in stock returns (Clement et al., 2011). As a result, returns on equity securities exhibit a strong contemporaneous relation with analysts' annual earnings forecast errors (Elgers and Murray, 1992; So, 2013). Our study controls for this relation and investigates how, without the influence of biased stock prices (analysts' forecasts), analysts' forecasts (stock prices) would respond to the persistence characteristics of free cash-flow and accrual earnings components derived from corporate annual reports.

Our disaggregation of annual net operating income into free cash-flow and accrual components follows Dechow et al. (2008) (hereafter DRS). We also apply the DRS technology in further disaggregating free cash flow into components that reflect how firms distribute (fund) the year's free cash-flow surplus (deficit). The firm can hold surplus free cash flow in the form of financial assets (i.e. cash) or distribute the surplus to investors (i.e. debtholders and stockholders). ${ }^{4}$ On the other hand, the firm can fund a free cash-flow deficit by reducing the firm's cash balance or by obtaining additional capital from debtholders and stockholders. Thus, we disaggregate free cash flow into its change in cash, net distributions to stockholders and net distributions to debtholders components.

We follow Richardson et al. $(2001,2006)$ in disaggregating accruals into sales growth and change in asset turnover (i.e. asset efficiency) components. Accruals (defined as changes in net operating assets) increase with increases in sales and, for a given level of sales, with decreases in asset efficiency, where asset efficiency equals sales divided by net operating assets.

We assess analyst and market efficiency with respect to persistence characteristics of net operating income as a whole and then disaggregated into the following: (i) free cash flow and accruals; (ii) free cash flow, sales growth and changes in asset efficiency; and (iii) accruals, changes in cash, net distributions to stockholders, and net distributions to debtholders. We assess analyst efficiency with and without controls for the influence of biases in stock returns, and we assess market efficiency with and without controls for the influence of biases in analysts' earnings forecasts.

In our sample of relatively large firms followed by analysts, we begin by estimating the persistence of annual net operating income and its components. Consistent with prior literature, we estimate that the persistence of the free cash-flow component of net operating income exceeds the persistence of the accrual component by $23 \%$, a difference that is economically and statistically significant. As expected, the sales growth component of accruals has significantly greater persistence than the change in efficiency component. All three components of free cash flow are highly persistent and, interestingly, the change

${ }^{4}$ Throughout the study, we simply refer to financial assets as cash. 
in cash variable has greater persistence than the net distributions to debtholder and stockholder variables.

To assess the bias in the stock price response to net operating income and its components, we regress returns for year $t+1$ on the year $t$ income variables described above. The return accumulation period extends for a full year beginning with the fifth month following the end of fiscal year $t$. To assess the bias in analysts' earnings forecasts, we estimate a regression of the year $t+1$ earnings forecast error on the year $t$ income variables.

The key results are summarised as follows. First, removing the influence of the bias in analysts' earnings forecasts, we find substantial evidence of market overweighting of the persistence of year $t$ operating income and its components. The evidence suggests that, without the influence of analysts' biased response to year $t$ earnings information, the stock market would overweight the persistence characteristics of the following: net operating income as a whole; the free cashflow and accrual components of net operating income; the sales growth and changes in asset efficiency components of accruals; and the change in cash and net distributions to debtholders components of free cash flow.

Second, by incorporating the influence of the bias in analysts' earnings forecasts, we find significant reduction of the market overweighting of the persistence of operating income and all components of cash and accrual earnings. Thus, biased analysts' earnings forecasts have the effect of mitigating market inefficiency.

Third, removing any influence of biased stock price response to year $t$ earnings information, we find that analysts' year $t+1$ earnings forecasts exhibit significant underweighting of the persistence of year $t$ net operating income and each of its cash and accrual components. Without removing any influence of biased stock price response, the only economically and statistically significant change is that we find no evidence of analyst underweighting of the persistence of the change in efficiency component of accruals. Thus, biased stock prices generally do not attenuate analyst underweighting of the implications of current earnings and its components for predictions of next year's earnings.

Overall, we conclude that, left to their own devices, analysts would generally underweight and stock prices would generally overweight the persistence characteristics of annual net operating income and its components. The general underweighting in analysts' earnings forecasts serves to attenuate the natural tendency of investors to overweight, and stock prices become more efficient. Mitigation of biased reaction to the persistence characteristics of earnings information is generally a one-way street, with analyst underweighting mitigating investor overweighting, and with market overweighting having virtually no effect on analyst underweighting.

This study makes important contributions to the literature. First, we bring a new perspective to the literature regarding the role of financial analysts in capital markets. Beginning with Abarbanell and Bernard (1992), many studies 
examine the role of financial analysts in relation to anomalous stock market behaviour. However, these studies invariably look to analysts for root causes of market inefficiency. Instead, we find that analysts play a disciplining role that reins in the tendency for investors and stock prices to overweight information about future earnings. Thus, the economic incentives leading to analyst underweighting could include an incentive to put the brakes on what otherwise would appear as generalised market overweighting of information about future earnings. Such an incentive could, for example, emerge from the degree to which analyst reputation and compensation depends on the profitability of trading strategies based on their forecasts and recommendations (Brown et al., 2015). Opposite-direction (same-direction) subsequent surprises generally follow overweighting (underweighting), and opposite-direction (same-direction) subsequent surprises are associated with losses (profits) to trading positions based on previous information (Raedy et al., 2006). We leave further investigation of such incentives for future research. Second, we draw attention to a technique that researchers can use to investigate the interaction of analyst and market inefficiency in other contexts.

The rest of this study is organised as follows. Section 2 reviews the most relevant literature. Section 3 provides a detailed description of our research design. Section 4 describes our sample, Section 5 presents our results, and Section 6 summarises and concludes the study.

\section{Prior research}

Beginning with Sloan (1996), researchers have investigated stock market efficiency with respect to information in accrual and cash-flow components of earnings. While Sloan examines the market's response to operating cash flows and working capital accruals minus depreciation, the research has evolved to consider the market response to total accruals, accruals disaggregated into various components, and free cash flows disaggregated into retained and distributed components.

Richardson et al. (2005) find that the market overweights the persistence of both current (non-cash working capital) and non-current operating accruals and that trading strategies based on total operating accruals generate more profits than strategies based on current operating accruals. Richardson et al. (2001, 2006) disaggregate total operating accruals into sales growth and asset efficiency (i.e. turnover) components. Richardson et al. (2001) find that the market overweights the persistence of both the sales growth and change in asset efficiency components of total accruals. The authors interpret this result to support both (i) the perspective of Fairfield et al. (2003), Cooper et al. (2005), and others that the accrual anomaly emerges from diminishing returns on firms' growth opportunities, and (ii) the perspective of Sloan (1996), Xie (2001), and others that the accrual anomaly emerges from accounting distortions. We 
extend this research by examining the role of financial analysts in the interpretation of information in components of free cash flows and accruals.

DRS demonstrate that the persistence of the free cash-flow component of accounting earnings depends on how the firm distributes (funds) free cash-flow surpluses (deficits). DRS find no evidence of market inefficiency with respect to the persistence of the portion of free cash flow that the firm distributes to (or obtains from) investors, whereas the market overweights the persistence of the portion of cash earnings that the firm retains (uses). This contradicts prior research evidence that the market underweights the persistence of total cash earnings (Sloan, 1996; Desai et al., 2004; Ahmed et al., 2006). ${ }^{5}$ In a sample of larger firms followed by analysts during a more recent time period, we reexamine the market's response to cash components of earnings and extend the literature by examining the role of analysts' forecasting behaviour in market efficiency.

Many research studies investigate the role of financial analysts in making the market inefficient. For example, Shane and Brous (2001) provide evidence attributing post-earnings and post-forecast revision drift to biases in analysts' quarterly earnings forecasts. La Porta (1996) and Doukas et al. (2002) suggest that analysts play a role in the value/glamour stocks anomaly. Dechow and Sloan (1997) suggest that analyst optimism influences market optimism with respect to firms' long-term growth prospects. Rajan and Servaes (1997), Dechow et al. (1999), Teoh and Wong (2002), and Purnanandam and Swaminathan (2004) provide evidence indicating that optimistic analyst earnings forecasts contribute to the long-run underperformance of IPOs and SEOs. Billings and Morton (2001) suggest that analyst forecasting biases contribute to the book-to-market anomaly. Bradshaw and Sloan (2002) attribute increasing manager and investor focus on upwardly biased 'street earnings' to financial analyst forecasting behaviour. Ikenberry and Ramnath (2002) suggest analyst responsibility for market underweighting of the signalling information in stock splits. Elgers et al. (2003) find a role for analysts in market overweighting the persistence of working capital accruals. Kadiyala and Rau (2004) find an association between analyst and investor underweighting of the future earnings implications of corporate events such as mergers and stock repurchases. Hribar and McInnis (2012) suggest that analysts influence investor sentiment. So (2013) develops a profitable trading strategy based on predictable financial analyst forecasting errors and, finally, Jackson and Johnson (2006) suggest that analyst forecasting biases play a role in anomalous returns momentum.

Some studies refer to market underweighting information in news and events and investigate the role of financial analysts in speeding up the market's

\footnotetext{
${ }^{5}$ Also see Chen and Shane (2014) who find that the market overweights the persistence of suboptimal decreases in cash and underweights the net distribution to stockholder component of free cash flow.
} 
assimilation of that information (e.g. Gurun et al. (2011) in the context of debt markets; and Hong et al. (2000) in the context of equity markets). Barth and Hutton (2004) suggest that analysts play a role in accelerating the market's correction of its overweighting of the accrual component of earnings, but they find that the market largely ignores adjustments in analysts' forecasts for the temporary nature of certain extreme accruals. Our study is the first to investigate whether the well-known restraint in analysts' earnings forecasts reins in what otherwise would be market overweighting the implications of current earnings (and its components) for predictions of future earnings, and we have a unique approach for doing so (described in Section 3 below).

\section{Research design}

\subsection{Earnings components}

Consistent with Dechow et al. (2008), we disaggregate earnings into free cash-flow (cash) and accrual components as follows (firm subscripts suppressed throughout all models). The balance sheet equation implies:

$$
\Delta A_{t}=\Delta L_{t}+\Delta S E_{t},
$$

where $t$ identifies the firm's fiscal year, $A_{t}=$ total assets, $L_{t}=$ total liabilities, and $S E_{t}=$ total stockholders' equity. ${ }^{6}$ Then, separating financing from operating activities yields:

$$
\triangle O A_{t}+\Delta C A S H_{t}=\Delta O L_{t}+\Delta F L_{t}+\Delta P S E_{t}+\Delta C S E_{t},
$$

where $O A_{t}=$ operating assets, $C A S H_{t}=$ all financial assets, $O L_{t}=$ operating liabilities, $F L_{t}=$ financial liabilities, $P S E_{t}=$ preferred stockholders' equity, and $C S E_{t}=$ common stockholders' equity. Rearranging terms:

$$
\triangle N O A_{t}=\triangle D E B T_{t}-\triangle C A S H_{t}+\triangle C S E_{t},
$$

where $N O A_{t}=O A_{t}-O L_{t}=$ net operating assets, and $D E B T_{t}=$ all nonowner financing, including financial liabilities, minority interest, and preferred stockholders' equity.

Assume clean surplus:

$$
\triangle C S E_{t}=N I_{t}-D I S T_{-} E Q_{t},
$$

where $N I_{t}=$ comprehensive income, and $D I S_{S_{-}} E Q_{t}=$ net distributions to common stockholders. $D I S T_{-} E Q_{t}$ represents distributions to common stock-

\footnotetext{
${ }^{6}$ The Appendix provides detailed definitions of each variable used in the study, along with Compustat labels.
} 
holders by way of dividends and stock repurchases net of new owner investment. Substituting the right-hand side of (4) for $\triangle C S E_{t}$ in (3), decomposing $N I_{t}$ into net operating income $\left(N O I_{t}\right)$ and net financing expense $\left(N F E_{t}\right.$ ), defining $D I S T_{-} D_{t}$ (net distributions to non-owner providers of financing) as $N F E_{t}-\triangle \bar{D} E B T_{t}$ and rearranging terms yield:

$$
N O I_{t}-\triangle N O A_{t}=\Delta C A S H_{t}+D I S T_{-} D_{t}+D I S T_{-} E Q_{t} .
$$

Thus, free cash flow generated by operations is represented on the left-hand side of (5) as net operating income less the change in net operating assets, and uses of free cash flow are represented on the right-hand side of (5) as the change in cash (buildup of the investment in financial assets) plus distributions to non-owner contributors of financing plus distributions to owners. All terms in (5) can be negative or positive; for example, when $N O I_{t}-\triangle N O A_{t}<0$, free cash flow is used in operations and the right-hand side of (5) must also be negative indicating the sources of the free cash flow used in operations (net decreases in the cash balance and/or net new investment by non-owner and owner providers of capital). Defining $\triangle N O A_{t}$ as accruals $\left(A C C_{t}\right)$ and $\triangle C A S H_{t}+D I S T_{-} D_{t}+D I S T_{-} E Q_{t}$ as free cash flow $\left(F C F_{t}\right)$ yields

$$
N O I_{t}=F C F_{t}+A C C_{t} .
$$

Thus, net operating income equals free cash flow (i.e. cash earnings) plus accruals (i.e. accrual earnings). Finally, deflate all terms by $N O A_{t-1}$ and define $N O I_{t} / N O A_{t-1}$ as $R N O A_{t}$.

$$
R N O A_{t}=F C F_{t}+A C C_{t},
$$

where $R N O A_{t}=N O I_{t} / N O A_{t-1}=$ return on net operating assets, $F C F_{t}=$ free cash flow deflated by lagged net operating assets, and $A C C_{t}=\triangle N O A_{t}$ deflated by lagged net operating assets. ${ }^{7,8}$

Following Richardson et al. (2001, 2006), we define and disaggregate total operating accruals as follows:

$$
A C C_{t}=S G_{t}+\left(-\Delta E F F_{t}\right)+S G_{t} *\left(-\Delta E F F_{t}\right),
$$

where $S G_{t}=\Delta$ Sales $_{t} /$ Sales $_{t-1}$ and represents sales growth; $\Delta E F F_{t}=\Delta A T_{t} /$ $A T_{t}$ and represents the change in asset efficiency measured as (Sales $t_{t}$ $N O A_{t}-$ Sales $\left._{t-1} / N O A_{t-1}\right) /\left(\right.$ Sales $\left._{t} / N O A_{t}\right)$, where $A T_{t} \quad\left(=\right.$ Sales $\left._{t} / N O A_{t}\right)$

\footnotetext{
7 Theoretically, the numerator in $R N O A_{t}$ should be $N O I_{t}$ (i.e., net operating income after tax). Following Richardson et al. (2005, 2006), we simply represent the numerator of $R N O A_{t}$ as income after depreciation (OIADP).

${ }^{8}$ Theoretically, distributions to preferred stockholders should be included in DIST_D. Following Dechow et al. (2008), we include distributions to/from preferred stockholders in $D I S T \_E Q$.
} 
provides an indication of asset turnover or asset efficiency. Richardson et al. (2006) provide an algebraic proof showing that the three terms on the RHS of (8) sum to total accruals $\left(A C C_{t}\right)$. The authors argue that this decomposition allows tests with the potential to distinguish between two competing explanations for the accrual anomaly: (i) market failure to fully impound mean reversion in sales growth (i.e. overweighting persistence of sales growth) versus (ii) market failure to fully impound information in accruals about temporary accounting distortions. Holding sales constant, the market might fail to impound the temporary nature of the portion of changes in NOA due to accounting distortions. If diminishing marginal returns on investment drive lower persistence of accruals, this should be reflected in the growth component of $A C C_{t}$ [i.e. $S G_{t}$ in Eqn (8)]. In contrast, if accounting distortion or declining operating asset efficiency drives lower persistence of accruals, then this should be reflected in the efficiency component of $A C C_{t}$ (i.e. $-\triangle E F F_{t}$ in Eqn (8)). ${ }^{9}$

Summarising (5), (7) and (8) above, our fully disaggregated model of net operating income becomes:

$$
\begin{aligned}
R N O A_{t}= & \left(\Delta C A S H_{t}+D I S T_{-} D_{t}+D I S T_{-} E Q_{t}\right)+\left[S G_{t}+\left(-\Delta E F F_{t}\right)\right. \\
& \left.+S G_{t} *\left(-\Delta E F F_{t}\right)\right],
\end{aligned}
$$

where the first bracketed term on the RHS of (9) disaggregates free cash flow $\left(F C F_{t}\right)$, and the second bracketed term disaggregates accruals $\left(A C C_{t}\right)$.

\subsection{Earnings persistence}

Replacing $R N O A_{t}$ in model (9) with $R N O A_{t+1}$, regression model (10) examines the persistence of net operating income and the components defined above.

$$
R N O A_{t+1}=\alpha_{0}+\sum_{i=1}^{n} \alpha_{i} C_{i t}+e_{t+1},
$$

where $C_{i t}$ represents component $i$ of $R N O A_{t}$ and $\alpha_{i}$ represents the persistence of component $i$ with reference to $R N O A_{t+1}$. That is, $\alpha_{i}$ indicates the degree to which the impact of $C_{i t}$ on $R N O A_{t}$ persists in terms of its relation to $R N O A_{t+1}$. We estimate four versions of the persistence model (10). In the first version, $n=1$ and $C_{1 t}=R N O A_{t}$. The second version disaggregates

\footnotetext{
${ }^{9}$ Results in Hribar and Yehuda (2008) suggest that market overweighing persistence of firms' growth opportunities, rather than overweighing persistence of accounting accruals, drives the accrual anomaly, particularly for growth firms early in their life cycle. If this is the case, then we expect that the sales growth component of Eqn (8) should drive any market overweighing of accruals.
} 
$R N O A_{t}$ into its two broad components, $F C F_{t}$ and $A C C_{t}$, that is $n=2$, $C_{1 t}=F C F_{t}$ and $C_{2 t}=A C C_{t}$. The third version follows Dechow et al. (2008) and disaggregates $F C F_{t}$ into $\triangle C A S H_{t}+D I S T_{-} D_{t}+D I S T_{-} E Q_{t}$, and the fourth version follows Richardson et al. $(2001,2006)$ and disaggregates $A C C_{t}$ into $S G_{t}+\left(-\Delta E F F_{t}\right)+S G_{t}{ }^{*}\left(-\Delta E F F_{t}\right)$. Disaggregated forms of (10) allow the components of $R N O A_{t}$ to have persistence coefficients that differ from each other. The residual, $e_{t+1}$, represents the portion of $R N O A_{t+1}$ that is not explained by the persistence of the components of $R N O A_{t}$ on the right-hand side of (10).

\subsection{Market efficiency}

Figure 1 describes our approach to evaluating the biases (if any) of market prices and analysts' forecasts with respect to the persistence characteristics of $R N O A_{t}$ and its components, $F C F_{t}$ and $A C C_{t}$. If the stock price, $P_{B}$, efficiently impounds the persistence characteristics of the components of $R N O A_{t}$, then we should find no

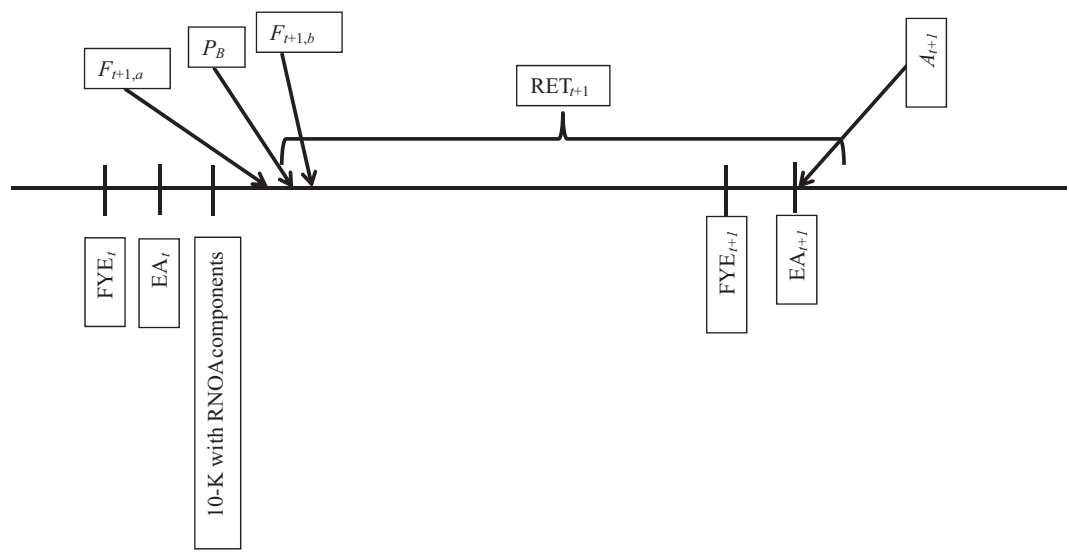

Figure 1 Biased market prices and analysts' earnings forecasts. $R E T_{t+1}$ represents the abnormal return on the firm's common stock, accumulated from the beginning of the fifth month of fiscal year $t+1$ (i.e. shortly after the release of the firm's year $t 10-\mathrm{K}$ ) and ending immediately after the firm's announcement of its earnings for year $t+1 . F E_{t+1, a}$ and $F E_{t+1, b}$, respectively, represent the difference between year $t+1$ actual earnings $\left(A_{t+1}\right)$ and the analyst's forecast of those earnings either just before $\left(F_{t+1, a}\right)$ or just after $\left(F_{t+1, b}\right)$ the beginning of the return accumulation period. $P_{B}$ represents the firm's stock price at the beginning of the return accumulation period, and $E A_{k}$ represents the announcement of earnings for year $k(k=t$ or $t+1)$. When we evaluate the influence of biased analyst forecasts on market prices, we use the most recent analyst forecast before the beginning of the return accumulation period to measure $F E_{t+1, a}$. When we evaluate the influence of market prices on the bias in analysts' forecasts, we use the first analyst forecast after the beginning of the return accumulation period to measure $F E_{t+1, b}$. If $F_{t+1, a}\left(P_{B}\right)$ is unbiased, then we should not find a relation between $F E_{t+1, a}\left(R E T_{t+1}\right)$ and the components of $R N O A_{t}$. 
relation between those components and abnormal stock returns computed with reference to $P_{B}$, where $P_{B}$ is the firm's stock price shortly after the firm's publication of its year $t 10-\mathrm{K}$ containing information about the detailed components of $R N O A_{t}$, including information investors might use to assess persistence.

Equation (11) below models abnormal returns as a function of the unexpected portion of $R N O A_{t+1}$, where returns are accumulated over a window beginning with $P_{B}$ and ending the day after the announcement of the firm's year $t+1$ earnings.

$$
R E T_{t+1}=\gamma+\beta\left[R N O A_{t+1}-\left(\alpha_{0}^{/}+\sum_{i=1}^{n} \alpha_{i}^{\prime} C_{i t}\right)\right]+u_{t+1},
$$

where $\alpha_{i}^{\prime}$ represents the market's perception of the persistence of earnings component $C_{i}$. Substituting the right-hand side of (10) for $R N O A_{t+1}$ in (11) and rearranging terms:

$$
R E T_{t+1}=\gamma+\beta\left[\left(\alpha_{0}-\alpha_{0}^{\prime}\right)+\sum_{i=1}^{n}\left(\alpha_{i}-\alpha_{i}^{\prime}\right) C_{i t}+e_{t+1}\right]+u_{t+1} .
$$

Substituting $\lambda_{0}$ for $\beta\left(\alpha_{0}-\alpha_{0}^{\prime}\right)$ and $\lambda_{i}$ for $\beta\left(\alpha_{i}-\alpha_{i}^{\prime}\right)$,

$$
R E T_{t+1}=\gamma+\lambda_{0}+\sum_{i=1}^{n} \lambda_{i} C_{i t}+\beta e_{t+1}+u_{t+1}
$$

where $\beta$ represents the earnings response coefficient, and $R E T_{t+1}=$ firm $i$ 's raw returns, accumulated from the fifth month following the end of fiscal year $t$ through the fourth month following the end of fiscal year $t+1$ minus the similarly accumulated mean return of all firms in the same size decile as firm $i$ (with size deciles formed as of the end of fiscal year $t$ ). If the market efficiently impounds the persistence characteristics of $R N O A_{t}$ and its various components, then $\alpha_{0}=\alpha_{0}^{\prime}, \alpha_{\mathrm{i}}=\alpha_{i}^{\prime}$, and the lambda coefficients in (13) are all zero. If the market overweights (underweights) the persistence of component $i$, then $\lambda_{i}<0$ $\left(\lambda_{i}>0\right){ }^{10}$

Next, we use model (14) below to assess the effect, if any, of financial analysts' earnings forecasts on any inefficiency in market prices detected in (13) above. If, as described in Figure 1, $F_{t+1 \text {,a }}$ systematically either overweights or underweights the persistence of components of $R N O A_{t}$, then we should observe a relation between $F E_{t+1, \mathrm{a}}$ and $R N O A_{t}$. Furthermore, if market prices rely on analysts to form annual earnings expectations (Brown et al., 1985), then we

\footnotetext{
${ }^{10}$ Rather than using the framework developed by Mishkin (1983), we use a conventional OLS model to test the rational expectations hypotheses. Kraft et al. (2007) show that OLS and the Mishkin test generate identical inferences in accounting settings when samples are large. The difference between actual and implied market persistence estimates is derived in model (13) by dividing each component variable coefficient by the residual variable coefficient.
} 
expect to find a relation between $F E_{t+1}$ and $R E T_{t+1}$. Thus, adding $F E_{t+1}$ to model (13) controls for the impact of any bias in analysts' response to the persistence characteristics of components of $R N O A_{t}$ on the market's response to those persistence characteristics.

$$
R E T_{t+1}=\gamma+\eta_{0}+\sum_{i=1}^{n} \eta_{i} C_{i t}+\beta e_{t+1}+\varphi F E_{t+1, a}+u_{t+1}
$$

where $F E_{t+1, \mathrm{a}}=\left(A_{t+1}-F_{t+1, \mathrm{a}}\right) / P_{B, t+1}, A_{t+1}$ is the firm's actual earnings (per $\mathrm{I} / \mathrm{B} / \mathrm{E} / \mathrm{S}$ ) announced at time $E A_{t+1}$ in Figure $1, F_{t+1, \mathrm{a}}$ is the most recent analyst forecast issued prior to the beginning of the return accumulation period (and after the announcement of year $t$ earnings), and $P_{B, t+1}$ is the stock price at the beginning of the return accumulation period. ${ }^{11}$ The $\eta_{i}$ coefficients in (14) represent the difference between actual persistence and market persistence perceptions without the influence of analysts' forecasts on market prices. If (14) produces $\eta_{i}$ estimates that are closer to (further from) zero than the corresponding $\lambda_{i}$ coefficients in (13), then analyst forecasting behaviour exacerbates (attenuates) the bias in the market's perception of the persistence of component $i$ of $R N O A_{t}$.

In other words, model (14) includes a forecast error variable that removes the variability in $R E T_{t+1}$ due to the influence of any biased forecast response to $R N O A_{t}$ and its components. If analyst forecasting behaviour attenuates market overweighting (underweighting) of the persistence characteristics of $R N O A_{t}$ and its components, then we expect the underweighting/overweighting coefficients to become increasingly negative (positive) and significant due to the inclusion of control variable $F E_{t+1, \mathrm{a}}$.

Including $F E_{t+1, \mathrm{a}}$ in the returns model above removes the impact (if any) of any biased analyst response to the persistence characteristics of $R N O A_{t}$ and its components on the estimated market underweighting/overweighting coefficients on $R N O A_{t}$ and its components. We are then left with underweighting/ overweighting coefficients reflecting the bias, if any, in how the market would have responded to $R N O A_{t}$ and its components without the influence of any analyst forecasting bias. Comparing the underweighting/overweighting coefficients in model (13) to the underweighting/overweighting coefficients in model (14) provides insight into the portion of the bias in the stock price response to

\footnotetext{
11 We follow the convention in prior literature that uses analyst-defined earnings to measure analyst forecast errors (Ramnath et al., 2005), whereas, as in Dechow et al. (2008), we use GAAP-defined earnings to evaluate the persistence of earnings components.
} 
$R N O A_{t}$ and its components due to, or mitigated by, bias in analysts' forecasting response to the same information. ${ }^{12}$

As described in Shane and Brous (2001), if analyst forecasting behaviour completely drives market inefficiency with respect to information about future earnings, then adding the forecast error variable to the returns regressions should make the coefficients on the information variables go to zero. On the other hand, if the market would have underweighted/overweighted $R N O A_{t}$ and its components without the influence of any bias in analysts' forecasts, then the underweighting (overweighting) coefficients should be significantly positive (negative) in model (14).

\subsection{Financial analyst efficiency}

Next, we assess whether any bias in the market's response to $R N O A_{t}$ and its components influences any bias in analysts' response to the same information. Model (15) below evaluates analyst one-year-ahead forecasting efficiency before controlling for effects of investor behaviour.

$$
F E_{t+1, b}=\gamma+a_{0}+\sum_{i=1}^{n} a_{i} C_{i t}+b e_{t+1}+u_{t+1},
$$

where $F E_{t+1, b}=\left(A_{t+1}-F_{t+1, \mathrm{~b}}\right) / P_{B, t+1}$, and $F_{t+1, b}$ is the first analyst forecast of year $t+1$ earnings issued during the fifth month of fiscal year $t+1$, that is after $P_{B}$ and the beginning of the return accumulation period.

If analysts issue efficient forecasts following firms' release of their financial statements containing cash and accrual components of earnings, then the information in those financial statements should not predict analysts' forecast errors $\left(F E_{t+1, b}\right)$, and the coefficients on the earnings variables, $C_{i t}$, should equal zero. The intercept term captures analysts' general optimism/pessimism. For example, a significantly negative intercept, $\gamma<0$ in model (15), indicates systematically optimistic $F_{t+1, b}$.

To remove any influence of biased stock price response to $R N O A_{t}$ and its components, model (16) adds year $t+1$ abnormal returns accumulated over

\footnotetext{
${ }^{12}$ Our technique for assessing market efficiency with and without the influence of biases in analysts' earnings forecasts relies on the following assumptions: (i) the relation between analyst error in forecasting year $t+1$ earnings and year $t$ earnings components effectively proxies for analyst forecasting bias; (ii) the relation between the year $t+1$ returns variable and year $t$ earnings components effectively proxies for investor forecasting bias; (iii) the relation between analyst error in forecasting year $t+1$ earnings and the year $t+1$ returns variable effectively proxies for the influence of analyst forecasts on investor forecasts; and (iv) adding the year $t+1$ analyst forecast error to a regression of the year $t+1$ returns variable on year $t$ earnings components effectively controls for the influence of analyst forecasting bias on investor forecasting bias.
} 
the period from the beginning of the fifth month of fiscal year $t+1$ through the day following $E A_{t+1}{ }^{13}$

$$
F E_{t+1, b}=\gamma+g_{0}+\sum_{i=1}^{n} g_{i} C_{i t}+b e_{t+1}+k R E T_{t+1}+u_{t+1} .
$$

Including $R E T_{t+1}$ in model (16) removes any impact of bias in the price reaction to the persistence characteristics of $R N O A_{t}$ and its components. If analyst forecasting behaviour simply mimics the behaviour of the marginal investor, then adding $R E T_{t+1}$ to the $F E_{t+1, b}$ regressions should make the underweighting/overweighting coefficients on $R N O A_{t}$ and its components go to zero. On the other hand, if, for example, investor overweighting attenuates analyst underweighting of the persistence of $R N O A_{t}$ and its components, then the coefficients in model (16) should become significantly positive and more so than in model (15).

\section{Sample}

As we rely on $\mathrm{I} / \mathrm{B} / \mathrm{E} / \mathrm{S}$ to measure the forecast error $\left(F E_{t+1, k}\right)$ variable, our sample represents larger firms and a more recent time period relative to the sample and time periods in Sloan (1996) and subsequent studies of market efficiency with respect to cash and accrual earnings components. Our time period spans the years 1988-2011.

To estimate the variables in our models, we obtain the following: financial statement data from Compustat; returns data from CRSP; and earnings forecasts, actual earnings, and stock prices from I/B/E/S. To increase the power of our tests, we rely on two samples. The first sample eliminates observations without the data needed to measure $F_{t+1, a}$, and the second sample eliminates observations without the data needed to measure $F_{t+1, b} . F_{t+1, a}$ is the most recent forecast during the period between the announcement of year $t$ earnings and the first day of the fifth month of fiscal year $t+1 . F_{t+1, b}$ is the first forecast of year $t+1$ earnings published during the fifth month of fiscal year $t+1$. As described above, we need $F_{t+1, a}\left(F_{t+1, b}\right)$ to examine the effect of analyst forecasting (market response) bias on biased market (analyst) perception of the persistence characteristics of $R N O A_{t}$ components. Table 1 describes the selection of these two samples. Sample 1 is larger than Sample 2, because we

\footnotetext{
${ }^{13}$ As described by Dechow et al. (2008), research evaluating delayed market response to year $t 10-\mathrm{K}$ information typically relies on returns accumulated from the beginning of the fifth month of the fiscal year $t+1$, as 'firms generally file Form 10-Ks within four months after the end of the fiscal year (p. 547)'. As a sensitivity check, we begin the return accumulation period on the day following the $10-\mathrm{K}$ filing date and obtain qualitatively similar results with no change in inferences drawn throughout the study.
} 
Table 1

Sample selection

\begin{tabular}{|c|c|c|}
\hline & Sample 1 & Sample 2 \\
\hline $\begin{array}{l}\text { All Compustat US firm- } \\
\text { years from } 1988 \text { to } 2011\end{array}$ & 185,751 & 185,751 \\
\hline $\begin{array}{l}\text { Exclude financial firms (SIC } \\
\text { codes 6000-6999) }\end{array}$ & $-35,882$ & $-35,882$ \\
\hline $\begin{array}{l}\text { Exclude firm-years missing } \\
\text { data needed to compute } \\
\text { cash-flow and accrual } \\
\text { earnings component } \\
\text { variables }\end{array}$ & $-48,195$ & $-48,195$ \\
\hline $\begin{array}{l}\text { Exclude firm-years where } \\
N O A,<0\end{array}$ & $-8,442$ & $-8,442$ \\
\hline Subtotal & 93,232 & 93,232 \\
\hline $\begin{array}{l}\text { Exclude firm-years without } \\
\text { matching CRSP data needed } \\
\text { to compute } R E T\end{array}$ & $-15,823$ & $-15,823$ \\
\hline Subtotal & 77,409 & 77,409 \\
\hline $\begin{array}{l}\text { Exclude firm-years without } \\
\text { matching } \mathrm{I} / \mathrm{B} / \mathrm{E} / \mathrm{S} \text { data } \\
\text { needed to compute } F E_{t,+}{ }_{1, k}\end{array}$ & $-35,484$ & $-46,356$ \\
\hline $\begin{array}{l}\text { Number of firm-years before } \\
\text { eliminating outliers }\end{array}$ & 41,925 & 31,053 \\
\hline $\begin{array}{l}\text { Exclude observations where the absolute } \\
\text { value of any of the following } \\
\text { variables is }>1: F E_{t}+1 \\
F C F_{t}, A C C_{t}, \Delta C A S H_{t}, \\
D I S T_{-} E Q_{t}, D I S T_{-} D_{t}, S G t \\
-\triangle E F F_{t}\end{array}$ & $-4,166$ & $-3,169$ \\
\hline $\begin{array}{l}\text { Number of firm-years in the } \\
\text { final sample }\end{array}$ & 37,759 & 27,884 \\
\hline
\end{tabular}

We use Sample 1 to evaluate analyst influence on biased market response to the persistence characteristics of operating income components, and we use Sample 2 to evaluate market influence on biased analyst response to the persistence characteristics of operating income components. Sample 1 requires at least one year $t+1$ earnings forecast published by $\mathrm{I} / \mathrm{B} / \mathrm{E} / \mathrm{S}$ during the period between the year $t$ earnings announcement and the first day of the fifth month of fiscal year $t+1$ (the beginning of the return accumulation period). Figure 1 refers to this forecast as $F_{t+1, a}$. Sample 2 requires at least one year $t+1$ earnings forecast published by $\mathrm{I} / \mathrm{B} / \mathrm{E} / \mathrm{S}$ during the fifth month of fiscal year $t+1$. Figure 1 refers to this forecast as $F_{t+1, b}$.

find more forecasts of year $t+1$ earnings published by $\mathrm{I} / \mathrm{B} / \mathrm{E} / \mathrm{S}$ during the period between the announcement of year $t$ earnings and the first day of the fifth month of fiscal year $t+1$ than during the course of the fifth month of fiscal year $t+1$. 
Table 1 shows that the initial sample contains 185751 firm-year observations on Compustat's Annual Industrial, Research, and Full Coverage files spanning the years 1988-2011. We exclude firms in the financial services industry $(35,882$ firm-years with SIC codes in the range 6000-6999). We omit 48,195 observations without Compustat data needed to compute our cash-flow and accrual earnings component variables. We exclude 8,442 observations with net operating assets less than zero. We lose 15,823 observations missing the CRSP data needed to compute our returns variable. In Sample 1 (Sample 2), we lose another 35,484 $(46,356)$ firm-year observations without I/B/E/S data needed to compute the forecast error variable, $F E_{t+1, a}\left(F E_{t+1, b}\right)$. Finally, Sample 1 (Sample 2) excludes 4,166 (3,169) outlier observations, with an earnings component or analyst forecast error variable greater than 1 or less than -1 . The final sample size consists of 37,759 $(27,884)$ firm-years spanning 1988-2011 for Sample 1 (Sample 2).

\section{Results}

\subsection{Descriptive statistics}

Table 2 presents descriptive statistics, including correlations between variables used in the study. Panel A describes Sample 1 and Panel B describes Sample 2. The two samples are quite similar, so we only discuss the Sample 1 descriptive statistics. Panel A shows that, as expected, the centre of the distribution of the abnormal returns variable is near zero (mean $R E T=0.006$ ), and its interquartile range is $38 \%$, so there is substantial variation to be explained. The forecast error variable is deflated by the stock price reported in the most recent $\mathrm{I} / \mathrm{B} / \mathrm{E} / \mathrm{S}$ report prior to the return accumulation period. ${ }^{14}$ Analysts provide slightly optimistic current-year forecasts for our sample firms (mean $F E_{t+1, a}<0$ ).

$R N O A_{t}$ is naturally deflated by beginning of year net operating assets, and the accrual and free cash-flow components of net operating income are similarly deflated. Panel A shows that, on average, 9\% $(91 \%)$ of the $10.9 \%$ mean return on net operating assets comes from the free cash-flow (accruals) component of net operating income. Specifically, the mean $F C F_{t}=0.8 \%$ and the mean $A C C_{t}=10.1 \%$; however, the median $F C F_{t}$ is $4.6 \%$ and the median $A C C_{t}$ is $5.7 \%$. $F C F_{t}\left(A C C_{t}\right)$ appears to be skewed towards the left (right) side of the distribution. Sales growth (mean $=10.9 \%$ ), rather than asset efficiency,

\footnotetext{
${ }^{14}$ As the stock price deflator could be contaminated by any market inefficiency with respect to the year $t$ earnings variables that are the subject of our evaluation of the relations between analyst and market efficiency, we conduct a sensitivity analysis using the following alternative deflators: book value of equity as of the end of fiscal year $t$, net operating assets as of the end of year $t$, absolute actual earnings per $\mathrm{I} / \mathrm{B} / \mathrm{E} / \mathrm{S}$, and, following Ahmed et al. (2006), average year $t$ total assets. The results and inferences are entirely robust to these alternative deflators.
} 
Table 2

Descriptive statistics

\begin{tabular}{|c|c|c|c|c|c|}
\hline Variable & 25th Pctl & Mean & Median & 75th Pctl & $\mathrm{SD}$ \\
\hline \multicolumn{6}{|c|}{ Panel A: Univariate statistics for sample 1} \\
\hline$R E T_{t}+1$ & -0.232 & 0.006 & -0.043 & 0.150 & 0.469 \\
\hline$F E_{t}+1, a$ & -0.017 & -0.016 & -0.002 & 0.004 & 0.074 \\
\hline$A_{t+1} / P_{B, t+1}$ & 0.030 & 0.035 & 0.054 & 0.075 & 0.133 \\
\hline$F_{t}+1, a / P_{B, t}+1$ & 0.040 & 0.050 & 0.060 & 0.079 & 0.113 \\
\hline$S G_{t}$ & 0.005 & 0.109 & 0.086 & 0.192 & 0.202 \\
\hline$-\triangle E F F_{t}$ & 0.097 & 0.004 & -0.018 & -0.115 & -0.225 \\
\hline$\triangle C A S H_{t}$ & -0.027 & 0.018 & 0.004 & 0.061 & 0.204 \\
\hline$D I S T_{-} E Q_{t}$ & -0.037 & 0.000 & 0.006 & 0.056 & 0.188 \\
\hline$D I S T_{-} D_{t}$ & -0.054 & -0.011 & 0.003 & 0.062 & 0.180 \\
\hline$F C F_{t}$ & -0.081 & 0.008 & 0.046 & 0.144 & 0.293 \\
\hline$A C C_{t}$ & -0.038 & 0.101 & 0.057 & 0.198 & 0.279 \\
\hline$R N O A_{t}$ & 0.054 & 0.109 & 0.107 & 0.184 & 0.246 \\
\hline
\end{tabular}

Panel B: Univariate statistics for sample 2

\begin{tabular}{|c|c|c|c|c|c|}
\hline$R E T_{t}+1$ & -0.229 & 0.006 & -0.042 & 0.151 & 0.465 \\
\hline$F E_{t}+1, b$ & -0.016 & -0.015 & -0.002 & 0.004 & 0.075 \\
\hline$A_{t}+{ }_{1} / P_{B, t}+1$ & 0.029 & 0.032 & 0.053 & 0.073 & 0.136 \\
\hline$F_{t}+1, b / P_{B, t}+1$ & 0.039 & 0.047 & 0.059 & 0.078 & 0.119 \\
\hline$S G_{t}$ & 0.007 & 0.114 & 0.088 & 0.198 & 0.205 \\
\hline$-\Delta E F F_{t}$ & 0.096 & 0.002 & -0.018 & -0.116 & -0.225 \\
\hline$\triangle C A S H_{t}$ & -0.026 & 0.019 & 0.004 & 0.059 & 0.200 \\
\hline$D I S T_{-} E Q_{t}$ & -0.038 & -0.002 & 0.006 & 0.055 & 0.187 \\
\hline$D I S T T_{t}$ & -0.057 & -0.012 & 0.004 & 0.063 & 0.184 \\
\hline$F C F_{t}$ & -0.081 & 0.004 & 0.045 & 0.141 & 0.294 \\
\hline$A C C_{t}$ & -0.035 & 0.104 & 0.059 & 0.200 & 0.280 \\
\hline$R N O A_{t}$ & 0.053 & 0.109 & 0.107 & 0.182 & 0.240 \\
\hline
\end{tabular}

See the Appendix for variable definitions.

fuelled the, on average, positive accruals during our sample period $($ mean $=10.1 \%)$.

Table 3 provides pairwise Pearson and Spearman correlations among the variables used in this study. Panel A applies to Sample 1 and Panel B applies to Sample 2. Again, the statistics are similar for the two samples, so we will only discuss Panel A. The significant positive contemporaneous correlation between $R E T_{t+1}$ and $F E_{t+1}$ (Pearson correlation coefficient $=0.24$, with $p<0.0001$ ) reflects strong common elements between the behaviour of analysts and investors. However, the correlation is far from perfect, which creates tension and makes it an empirical question as to whether bias in the $F_{t+1, a}$ creates bias in market price $P_{B}$ and whether $P_{B}$ creates bias in $F_{t+1, b}$.

On a univariate basis, consistent with Sloan (1996), it appears that investors overweight accruals persistence and underweight free cash-flow persistence, 


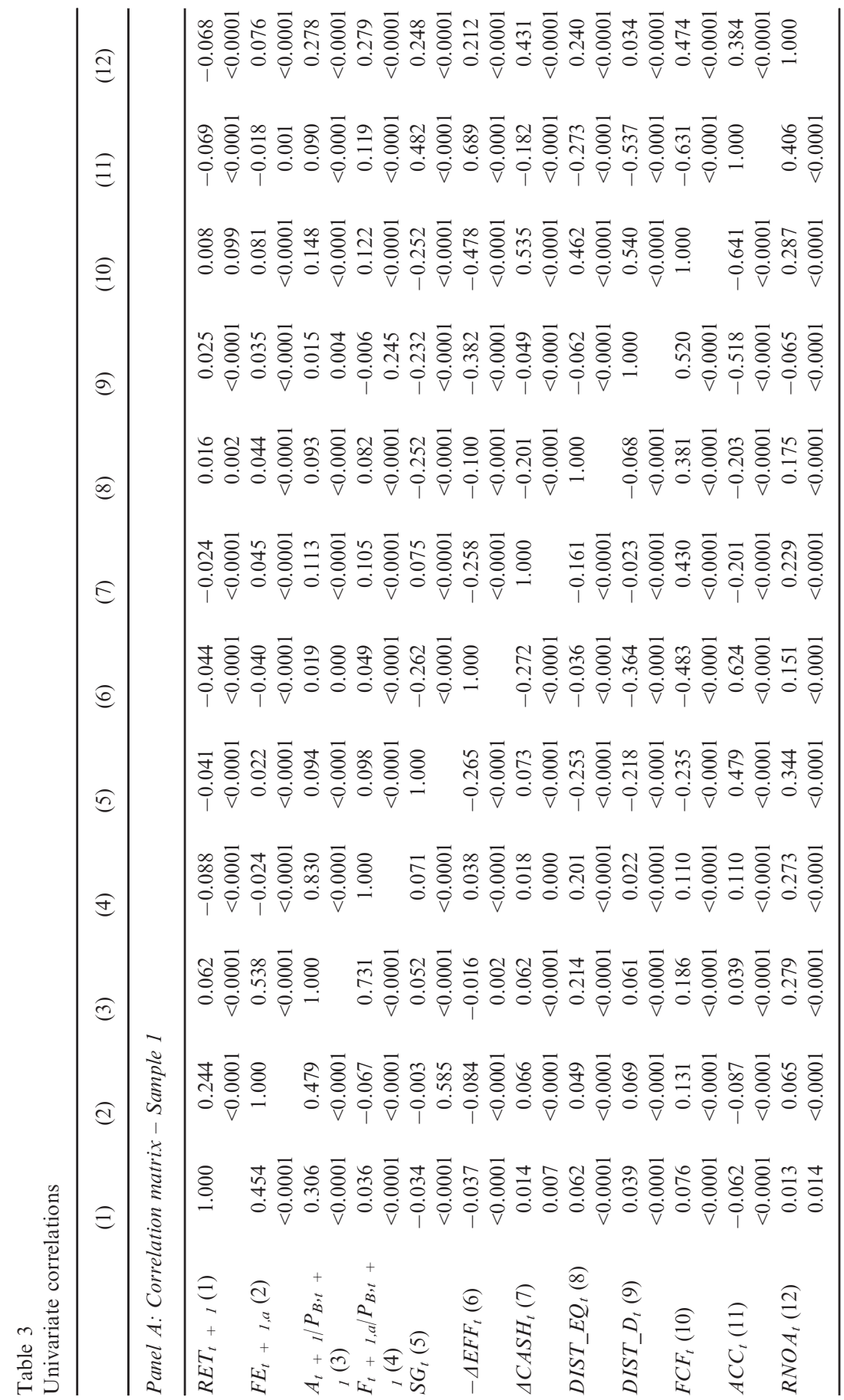




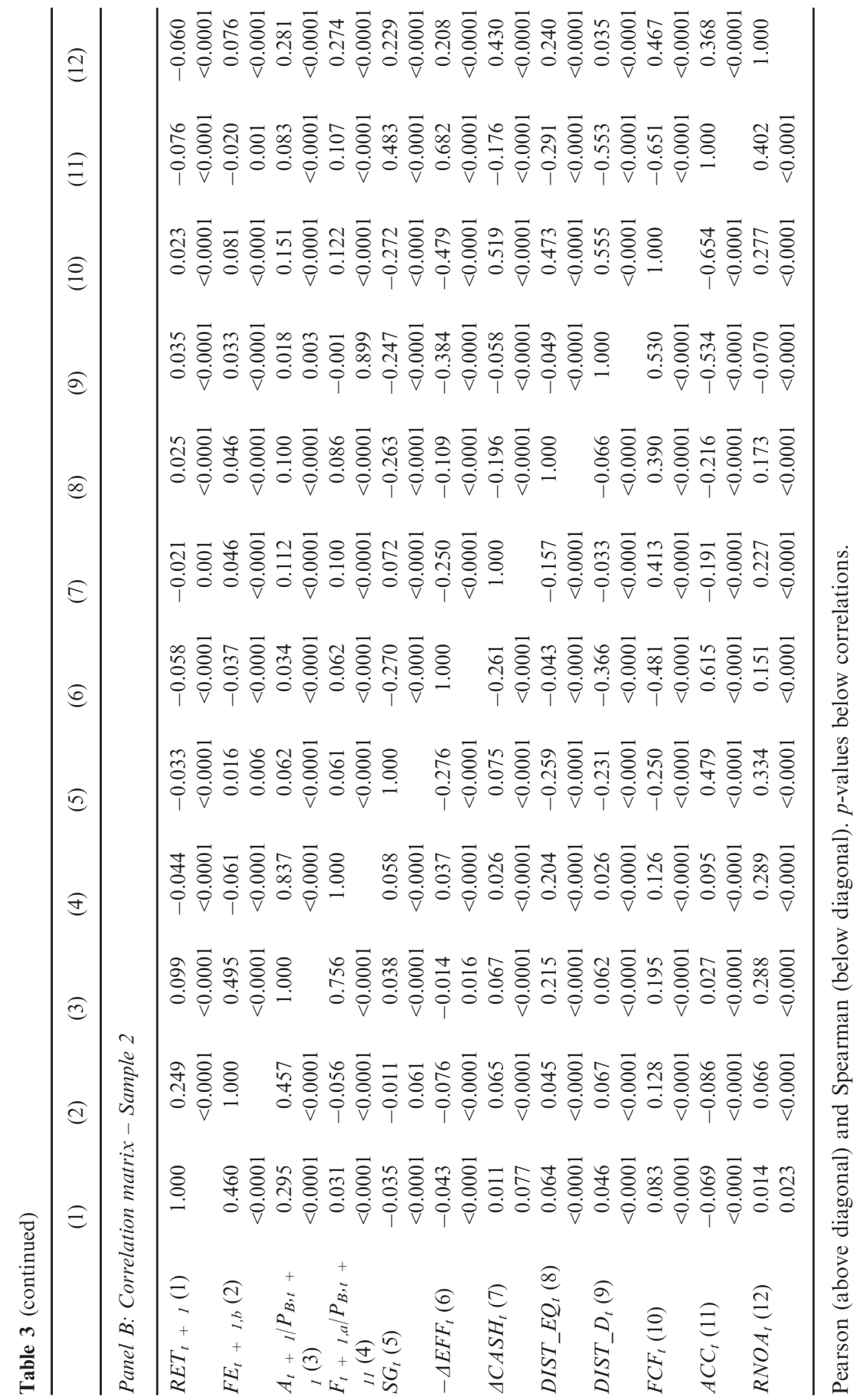


respectively, as we find a significant negative correlation between $A C C_{t}$ and $R E T_{t+1}$ and a significant positive correlation between $F C F_{t}$ and $R E T_{t+1}$. Investors appear to overweight both components of accruals persistence, as we find significant negative correlation between $S G_{t}$ and $R E T_{t+1}$ and between $-\triangle E F F_{t}$ and $R E T_{t+1}$. Consistent with Dechow et al. (2008), the significant positive correlation between returns and distributions to both stockholders and debtholders drives the significant positive correlation between free cash flow and next year's returns. Finally, the significant negative Pearson correlation coefficient relating $\triangle C A S H_{t}$ to $R E T_{t+1}$ supports Dechow et al.'s inference that investors overweight the change in cash component of free cash flow, although the Spearman correlation between $\triangle C A S H_{t}$ and $R E T_{t+1}$ is significantly positive.

Turning to analyst forecasting behaviour, consistent with Bradshaw et al. (2001), the univariate correlations in Table 3 Panel B suggest that analysts overweight the persistence of accruals (significant negative correlation between $A C C_{t}$ and $\left.F E_{t+1}\right) .{ }^{15}$ Also, it appears that analysts underweight free cash-flow persistence (significant positive correlation between $F C F_{t}$ and $F E_{t+1}$ ). Univariate statistics suggest that analyst underweighting of free cash-flow persistence permeates all three free cash-flow components: $\triangle C A S H_{t}, D I S T_{-} D_{t}$ and $D I S T \_E Q_{t}$.

The univariate correlation matrix suggests that investors and analysts overweight the efficiency change component of accruals persistence. Table 3 reports a significant negative correlation between $-\triangle E F F_{t}$ and $F E_{t+1}$, and a significant negative correlation between $-\triangle E F F_{t}$ and $R E T_{t+1}$. The highly significant negative correlation between $F C F_{t}$ and $A C C_{t}$ (Pearson $=-0.63$ and Spearman $=-0.64)$ means a multivariate test is required to identify each variable's unique relation with future returns $\left(R E T_{t+1}\right)$ and future forecast errors $\left(F E_{t+1}\right) .{ }^{16}$ Thus, conclusions, drawn from univariate statistics in Table 3, about analyst/market overweighting/underweighting of the persistence of free cash-flow and accrual earnings components are premature. It is not clear at this stage whether analyst behaviour attenuates or exacerbates biased market perception of the persistence characteristics of components of operating income. Nor is it clear at this stage whether market price behaviour attenuates or exacerbates biased analyst perception of the persistence characteristics of components of operating income. Our multivariate tests that follow are designed to more rigorously address these questions.

\footnotetext{
15 As explained by Drake and Myers (2011), many subsequent studies interpret the Bradshaw et al. (2001) evidence to mean that analysts overweight the persistence characteristics of accruals (Thomas and Zhang, 2002; Collins et al., 2003; Elgers et al., 2003; Hanlon, 2005; Mashruwala et al., 2006).

${ }^{16}$ See Ahmed et al. (2006) and Drake and Myers (2011) for similar attention to this issue.
} 


\subsection{Earnings persistence}

Table 4 shows that the cash and accrual earnings components, derived from our sample, exhibit persistence characteristics consistent with prior literature. Again, Panel A (Panel B) describes the results for Sample 1 (Sample 2), and as the results are similar, we only discuss Panel A. As described by the regression in Panel A, return on net operating assets persists strongly from one year to the next. The regression of $R N O A_{t+1}$ on $R N O A_{t}$ has a highly significant slope coefficient of 0.63 , and the adjusted $R^{2}$ statistic indicates that $R N O A_{t}$ explains 32 percent of the variation in $R N O A_{t+1}$. Panel A shows that coefficients relating cash and accrual earnings to next year earnings are 0.69 and 0.56 , respectively, and while both coefficients are significantly greater than zero, they are also significantly different from each other $(p<0.0001) .{ }^{17}$ Consistent with Dechow (1994), Sloan (1996) and Barth et al. (2001), cash flows are significantly more persistent than accruals.

Table 4 provides evidence that every component of cash and accrual earnings is highly persistent. Each disaggregated cash and accrual earnings component is significantly related to $R N O A_{t+1}$ with the expected sign. The persistence parameters range from a low of 0.48 on the efficiency change component of accruals to a high of 0.71 on the retained cash component of free cash flow. Untabulated $F$-tests show that each coefficient estimate is significantly different from each other, at the one percent level. Thus, disaggregating earnings into components that have different persistence characteristics provides useful information for purposes of forecasting earnings and valuing securities.

\subsection{Market efficiency}

Table 5 describes the behaviour of stock returns following publication of financial statements with enough information to disaggregate earnings into the accrual and cash components described in Table 4 and model (10). In Panel A, estimates of model (14) coefficients indicate that, controlling for the bias in analysts' forecasts, the market's overweighting coefficient equals $-0.13(t$-statistic $=-2.63)$ with reference to net operating income as a whole. Removing the control variable, the ostensible market overweighting coefficient is statistically insignificant at $-0.08(t$-statistic $=-1.61)$, and the $p$-value associated with the 37 percent decline in absolute value from -0.13 to -0.08 is $<0.01$. Apparently, with reference to the persistence of $R N O A_{t}$, underweighting bias in analysts' earnings forecasts attenuates the overweighting in stock market prices to the point where it registers as statistically insignificant.

${ }^{17}$ All $p$-values refer to two-tailed significance levels. 
Table 4

Persistence of components of cash and accrual earnings

\begin{tabular}{|c|c|c|c|c|}
\hline \multicolumn{4}{|c|}{$R N O A_{t+1}=\alpha_{0}+\sum_{i=1}^{n} \alpha_{i} C_{i t}+e_{t+1}$} & \multirow{2}{*}{$\frac{(10)}{\text { Coeff. (t-stat.) }}$} \\
\hline Variable & Coeff. (t-stat.) & Coeff. (t-stat.) & Coeff. (t-stat.) & \\
\hline \multicolumn{5}{|c|}{ Panel A: Sample 1 (37,759 observations spanning the years 1988-2011) } \\
\hline Intercept & $0.033(5.55)$ & $0.038(6.51)$ & $0.031(5.13)$ & $0.039(6.50)$ \\
\hline$R N O A$ & $0.627(41.80)$ & & & \\
\hline$F C F$ & & $0.686(48.26)$ & $0.677(49.00)$ & \\
\hline$A C C$ & & $0.556(29.16)$ & & $0.535(26.79)$ \\
\hline$\triangle C A S H$ & & & & $0.713(43.95)$ \\
\hline$D I S T \_E Q$ & & & & $0.679(38.84)$ \\
\hline$D I S T_{-} D$ & & & & $0.619(32.36)$ \\
\hline$S G$ & & & 0.639 (29.89) & \\
\hline$-\triangle E F F$ & & & $0.481(21.15)$ & \\
\hline$-S G_{t} * \triangle E F F$ & & & $0.643(17.13)$ & \\
\hline Adj. $R^{2}$ & 0.317 & 0.335 & 0.345 & 0.340 \\
\hline
\end{tabular}

Panel B: Sample 2 (27,884 observations spanning the years 1988-2011)

\begin{tabular}{|c|c|c|c|c|}
\hline Intercept & $0.037(6.38)$ & $0.042(7.28)$ & $0.034(5.94)$ & $0.043(7.15)$ \\
\hline$R N O A$ & $0.608(45.17)$ & & & \\
\hline$F C F$ & & $0.664(49.58)$ & $0.656(50.21)$ & \\
\hline$A C C$ & & $0.539(30.63)$ & & $0.519(27.63)$ \\
\hline$\triangle C A S H$ & & & & $0.691(40.90)$ \\
\hline$D I S T \_E Q$ & & & & 0.653 (41.47) \\
\hline$D I S T \_D$ & & & & $0.603(30.31)$ \\
\hline$S G$ & & & $0.620(31.75)$ & \\
\hline$-\triangle E F F$ & & & $0.457(21.90)$ & \\
\hline$-S G_{t} * \Delta E F F$ & & & $0.678(17.87)$ & \\
\hline Adj. $R^{2}$ & 0.296 & 0.314 & 0.325 & 0.319 \\
\hline
\end{tabular}

The Fama-MacBeth procedure is employed to run cross-sectional regressions (associated $t$ statistics in parentheses). See the Appendix for variable definitions.

As shown in Panel B, with $F E_{t+1}$ in the model, the coefficient relating $A C C_{t}$ to $R E T_{t+1}$ equals -0.17 and is significantly less than zero $(t$-statistic $=-3.21)$. Removing $F E_{t+1}$ from the model reduces the estimated market overweighting coefficient by $23 \%$ (from -0.17 to -0.13 ). This decline in market overweighting associated with allowing the influence of biased analyst forecasts is statistically significant $(p<0.01)$. Apparently, analyst inefficiency with respect to the persistence of accrual earnings significantly attenuates, but does not render insignificant, the market overweighting.

Panel B shows that with $F E_{a, t+1}$ in the model, the coefficient relating $F C F_{t}$ to $R E T_{t+1}$ equals $-0.10(t$-statistic $=-2.02)$. Removing $F E_{t+1}$ from the model reduces the estimated market overweighting coefficient by $57 \%$ (from -0.10 to 


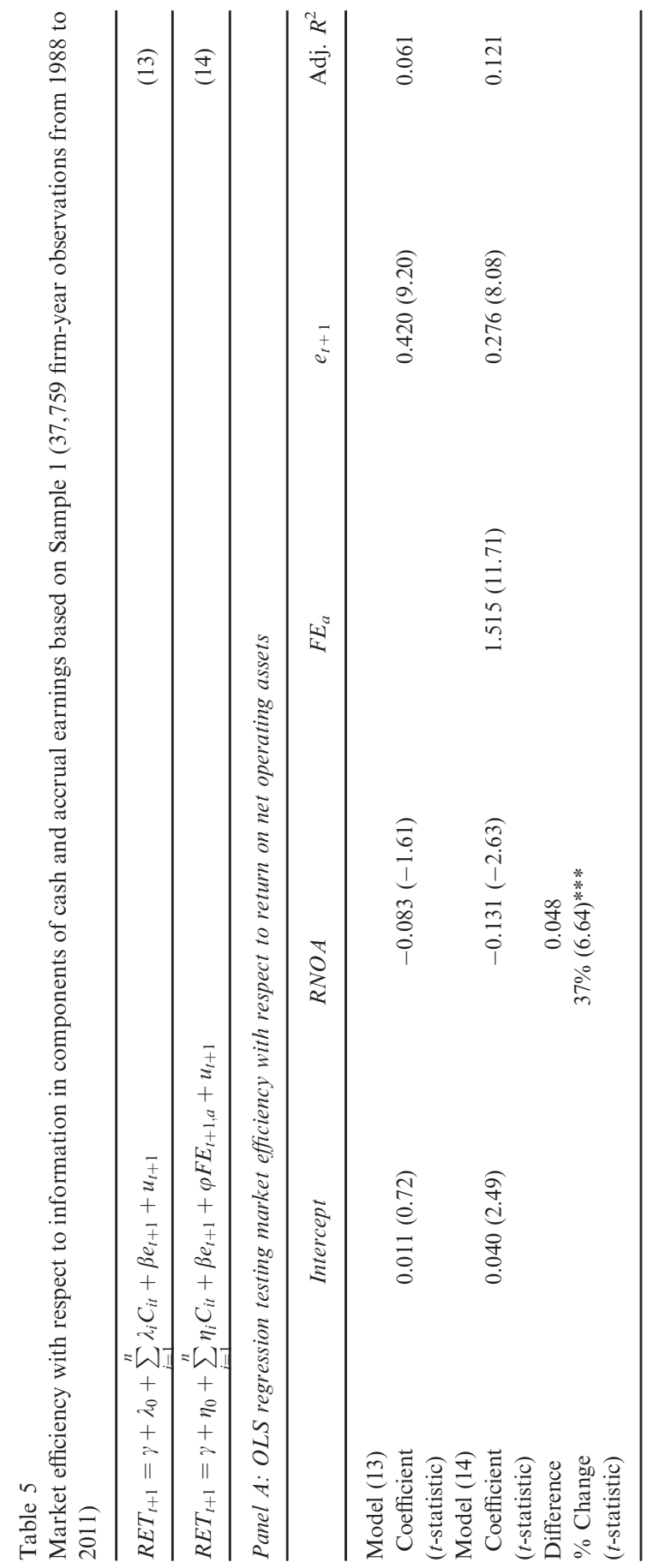




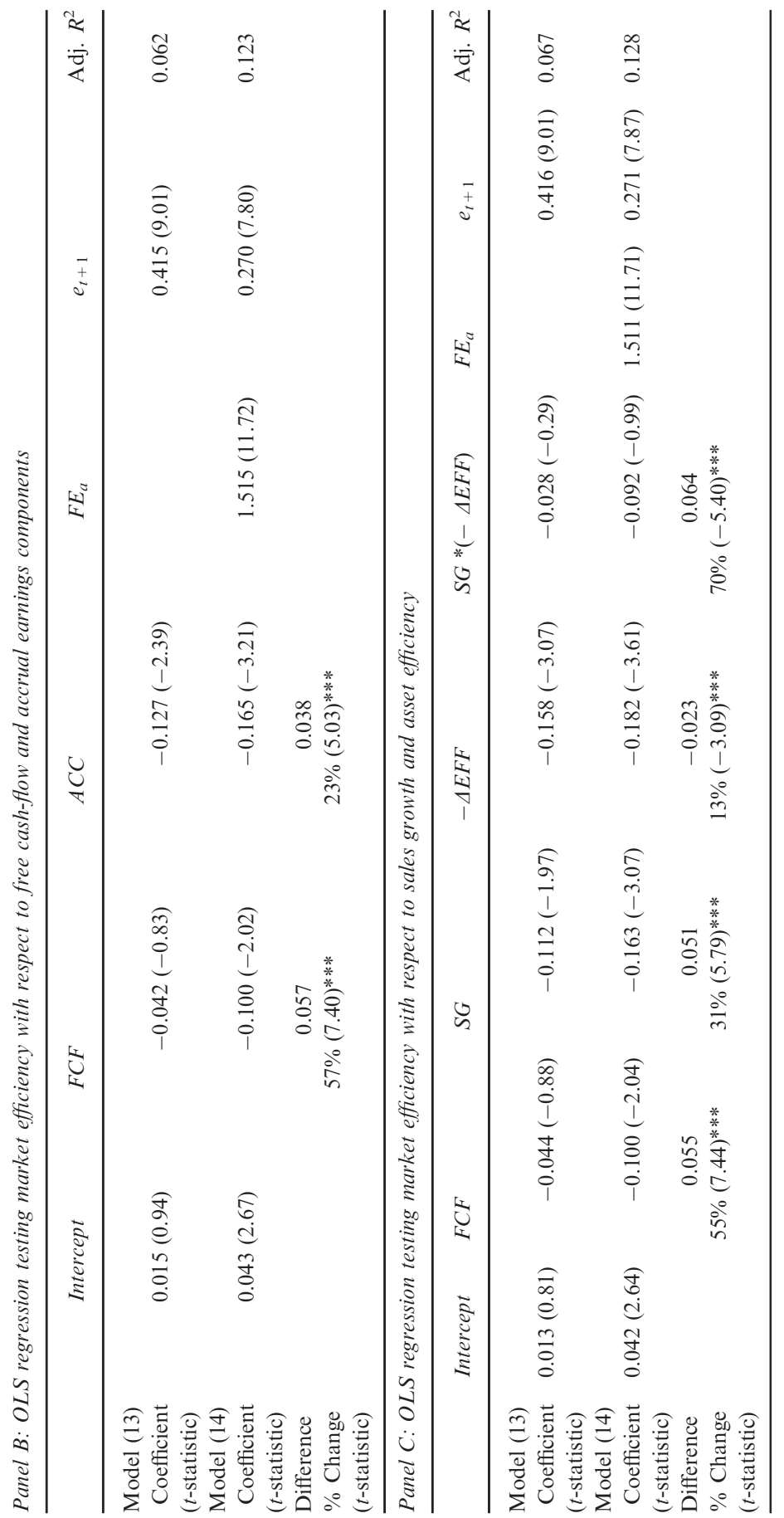




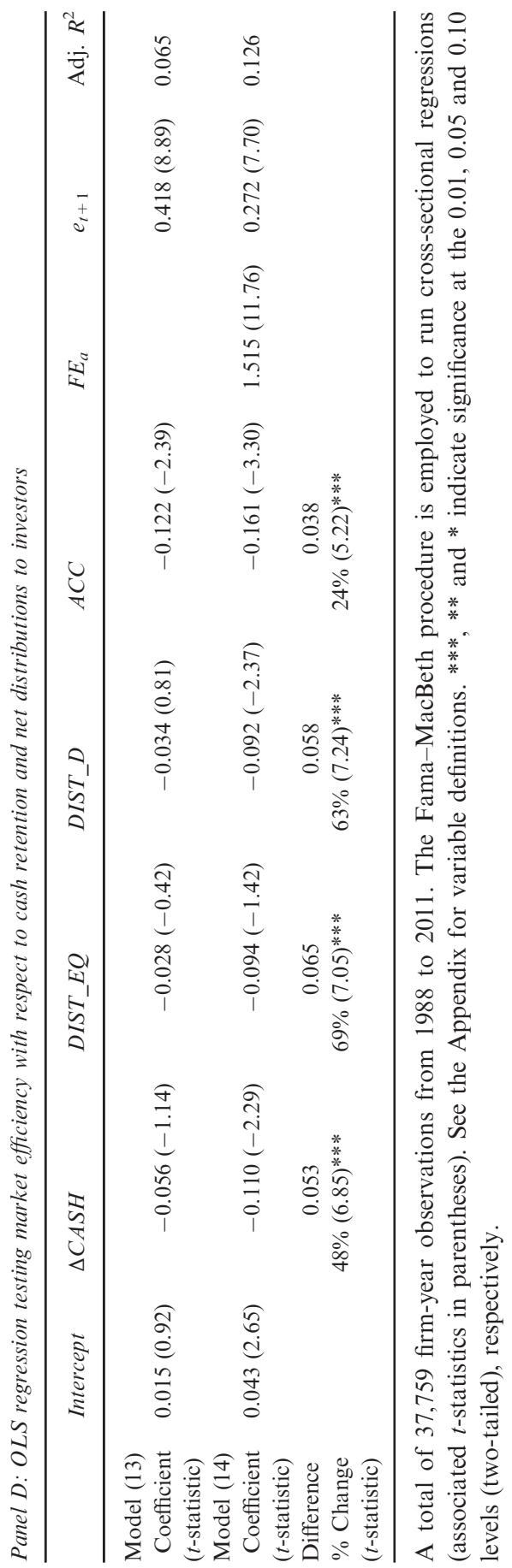


-0.04). This decline in market overweighting associated with allowing the influence of biased analyst forecasts is statistically significant $(p<0.01)$. Apparently, analysts' underweighting bias with respect to the persistence of free cash flow significantly attenuates the market's tendency towards overweighting. ${ }^{18}$

A picture of analyst underweighting and investor overweighting of the persistence of annual earnings and its components is beginning to emerge. Without controlling for analyst underweighting, the strong positive relation between $R E T_{t+1}$ and $F E_{t+1}$ obscures the influence of analyst forecasting bias on stock price overweighting of the persistence of $R N O A_{t}$ and its components. Controlling for the strong positive relation between investor and analyst behaviour, we find evidence of general market overweighting of both cash and accrual earnings components. The market overweighting of cash earnings persistence that would occur without the influence of the bias in analysts' forecasts is a new result, inconsistent with inferences drawn from Sloan (1996) and the many studies that followed.

Panel C of Table 5 replicates the Richardson et al. (2001) analysis of the relation of cash flow and disaggregated accrual earnings components with following year returns. Before controlling for analyst behaviour, both accrual components of earnings are negatively related to future returns (indicating overweighting). Panel $\mathrm{C}$ shows that controlling for the mitigating influence of analysts' forecasts, the coefficients relating the sales growth and change in efficiency components of year $t$ accrual earnings to year $t+1$ returns are -0.16 and -0.18 with $t$-statistics of -3.07 and -3.61 , respectively. Omitting $F E_{t+1}$ from the model shows that the mitigating influence of biased analyst forecasts reduces market overweighting by a statistically significant 31 and 13 percent, respectively. Thus, controlling for analyst forecasting behaviour, estimation of model (14) in Panel C reveals generalised market overweighting of free cash-flow persistence and both components of accruals persistence. Apparently, analyst underweighting attenuates investors' tendency to overweight and leaves the market with a relatively efficient price with respect to persistence characteristics of $F C F_{t}$, and with a significantly reduced overweighting of the persistence of sales growth and asset efficiency components of accrual earnings. We will explore the efficiency of the analyst reaction more directly in Table 6, but the evidence in Table 5 suggests that analysts underweight the free cash flow, sales growth and asset efficiency components of net operating income persistence.

Finally, Panel D of Table 5 shows that, without controlling for analyst forecasting behaviour, estimates of coefficients in model (13) show no evidence of market inefficiency with respect to the components of free cash flow. However, controlling for $F E_{t+1}$ in model (14) reveals the mitigating influence of biased analyst forecasts on what otherwise would appear as market

18 Similarly, Louis et al. (2013) find that analysts' forecasts following management forecasts appear to adjust for the lack of persistence in abnormal accruals. This analyst forecasting behaviour appears to attenuate the abnormal accrual anomaly. 


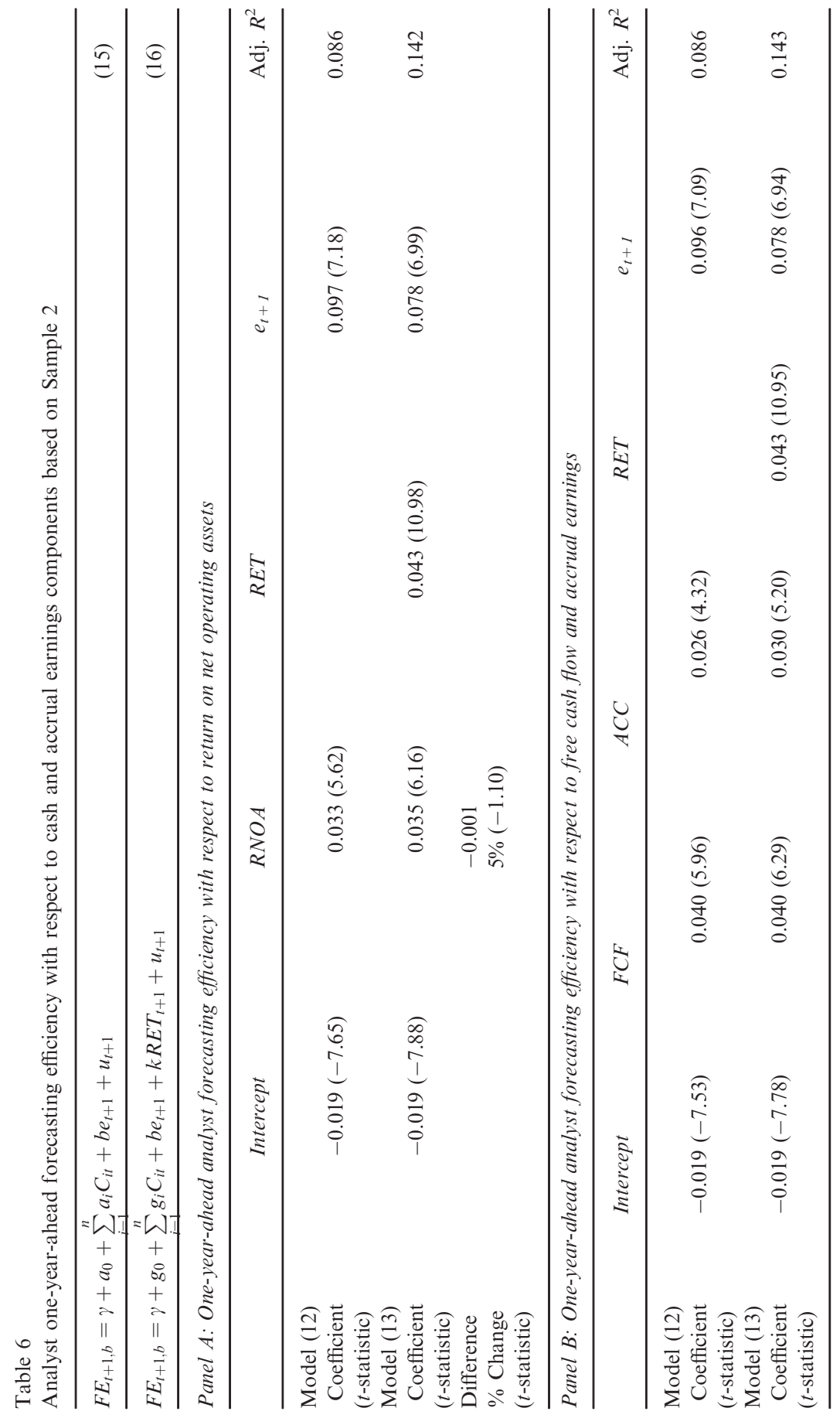




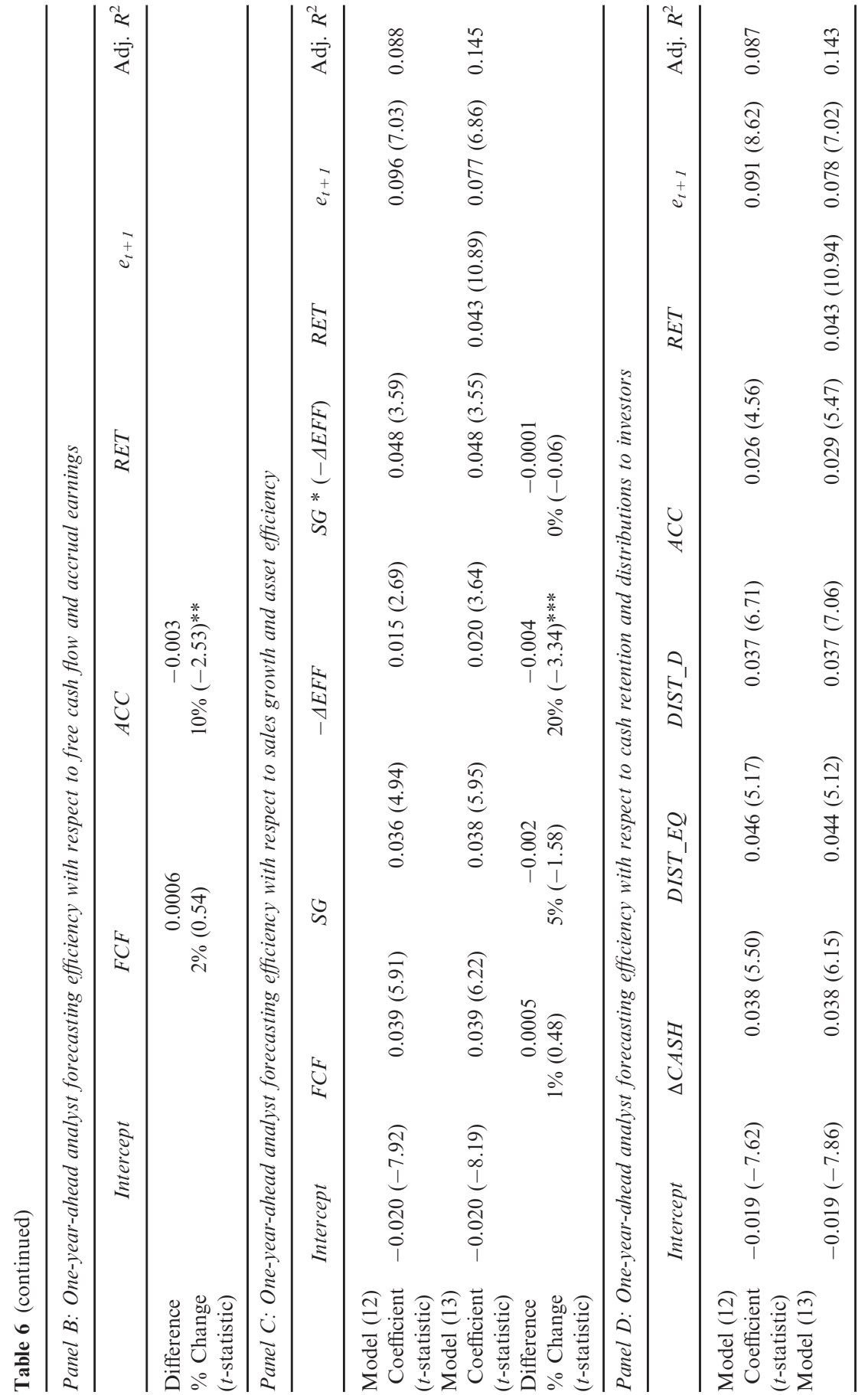




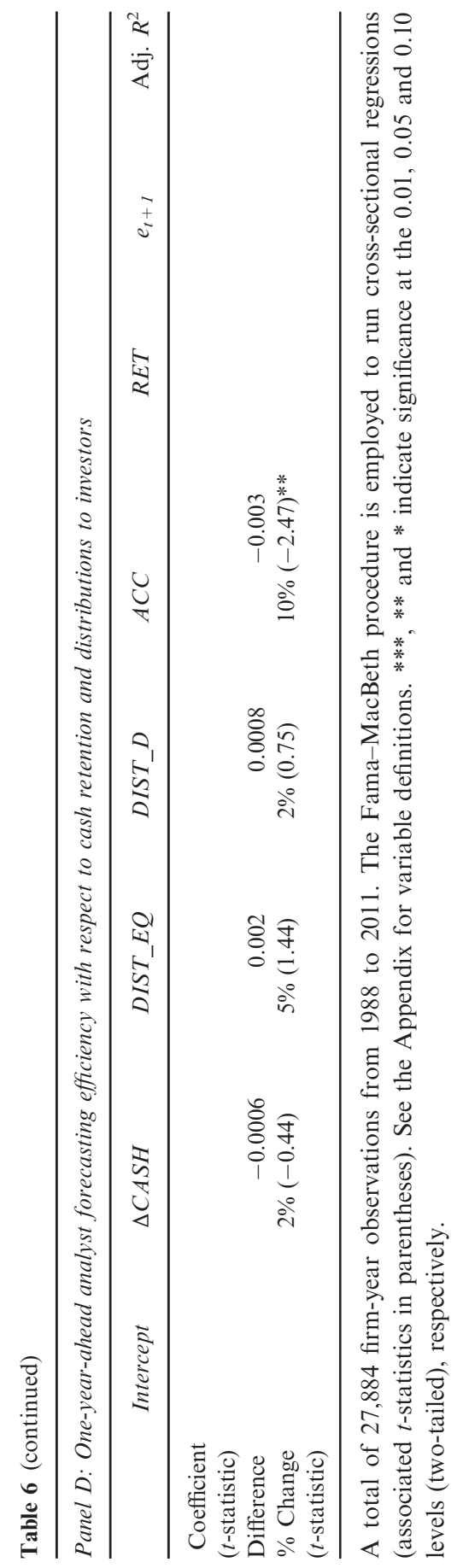


overweighting of the retained cash and distribution to debtholder components of cash earnings persistence. The overweighting coefficients on all three components of free cash flow decline significantly in absolute value when we remove $F E_{t+1}$ from the model, thus allowing the mitigating influence of analyst forecasting behaviour on the tendency of the market to overweight the persistence characteristics of free cash flow and its components. In particular, the coefficients on $\triangle C A S H, D I S T_{-} E Q$, and $D I S T_{-} D$ decline by statistically significant amounts equal to 48,69 , and 63 percent, respectively. The overall findings from Table 5 show that the market overweights both accrual and cash earnings persistence, after controlling for analyst behaviour. Biased analysts' earnings forecasts, following the release of year $t$ financial reports, attenuate market overweighting of both cash and accrual components of net operating income persistence.

We interpret the findings in Table 5 as follows. Left to their own devices, individual investors tend to overweight the persistence of annual earnings information and its free cash-flow and accrual components. However, the market of investors apparently pays attention to analysts' interpretation of accounting information (Gleason and Lee, 2003; So, 2013). Therefore, analysts' underweighting of the persistence of earnings and its components attenuates the market overweighting. We suspect that analysts' forecasts tend to underweight accounting information due to analysts' economic incentives (Raedy et al., 2006), whereas individual investors tend to overweight accounting information for yet to be determined psychological or economic reasons.

\subsection{Financial analysts' forecast efficiency}

Table 6 describes the efficiency of analysts' year $t+1$ earnings forecasts after the beginning of the 12 month accumulation period, with respect to year $t$ earnings information. We infer analyst underweighting/overweighting with reference to the expectations adjustment implied by the year $t+1$ annual earnings announcement that occurs one trading day before the end of the return accumulation period. If analysts' forecasts efficiently impound the information in earnings and its components, then slope coefficients should not differ from zero in regressions of our expectations adjustment variable, $F E_{t+1}$, on year $t$ earnings variables. Instead, Table 6 Panels $\mathrm{A}$ and $\mathrm{B}$ report significantly positive coefficients on $R N O A_{t}$ and both $F C F_{t}$ and $A C C_{t}$.

From Table 5, we infer that investors overweight information about the persistence of earnings and its components, and from Table 3, we infer that there is a strong positive univariate relation between analyst errors in forecasting year $t+1$ earnings and returns during the return accumulation period. With and without controls for investor overweighting, the significantly positive coefficients on $R N O A_{t}$ (Panel A) and on both $F C F_{t}$ and $A C C_{t}$ (Panel B) suggest that analysts underweight the persistence of both free cash-flow and accrual components of earnings. This result is inconsis- 
tent with Drake and Myers (2011) which concludes that, like investors, analysts overweight the persistence of accruals.

Our study differs from Drake and Myers (2011) (hereafter DM) in several important ways. First, our sample period covers the years 1988 through 2011, whereas the DM sample covers the years from 1993 through 2008. Second, DM compute annual forecast errors with reference to forecasts made between 30 days and one year prior to the fiscal year-end date, whereas we rely on forecasts made around the time of the beginning of our return accumulation period, that is four months after the end of fiscal year $t$ (Figure 1). Third, DM evaluate analyst forecasting efficiency with respect to working capital accruals and operating cash flows, whereas we follow DRS and evaluate forecasting efficiency with respect to total accruals and free cash flow. Fourth, DM's tests are at the analyst level, with approximately 15 observations per analyst-specific regression, whereas our tests are conducted across firms within years, and we have approximately 1500 observations per annual regression. Fifth, DM deflate their earnings component variables by equity market value, whereas we deflate by net operating assets to disaggregate our measure of operating earnings (return on net operating assets) into its component parts. Finally, DM use the prior year's analyst forecast error as a control variable, whereas our theoretically based control variable comes from the residual of the model that predicts RNOA during the prior year. We follow DRS and derive all of our earnings variables from algebraic disaggregation of RNOA, whereas DM's earnings components, also based on prior literature, are more ad hoc. ${ }^{19,20}$

Turning to analyst year $t+1$ forecasting efficiency with respect to the information in detailed components of accrual earnings, Panels $\mathrm{C}$ and $\mathrm{D}$ show that the analyst underweighting coefficient on all components of cash and accrual earnings remains statistically significant and barely moves with the removal of the influence of investor overweighting of the same earnings information. The most movement occurs in estimated analyst underweighting of the efficiency change component of accrual earnings. Allowing for the influence of investor overweighting of that component of accrual earnings is associated with a statistically significant $20 \%$ decline in the analyst underweighting coefficient from 0.020 to 0.015 . We find no evidence of investor overweighting of the persistence of other components of cash and accrual earnings influencing analyst underweighting, as

\footnotetext{
${ }^{19}$ Our inference that analysts underweight the persistence of accrual earnings is also inconsistent with Bradshaw et al. (2001), but we are able to replicate the Bradshaw et al. (2001) results by omitting the free cash-flow component of earnings from the model. Thus, like Ahmed et al. (2006) and Drake and Myers (2011), we conclude that Bradshaw et al. inferences suffer from an omitted variable problem.

${ }^{20} \mathrm{We}$ are aware of only one other study of analyst forecasting efficiency with respect to the persistence of cash earnings. In that study, unlike DM but like our study, Yu (2007) finds that analysts' quarterly earnings forecasts underweight the implications of the prior year's cash earnings.
} 
declines in analyst underweighting are statistically insignificant with respect to all other components of cash and accrual earnings. The change in efficiency component of year $t$ accrual earnings is the only place where we observe a significant mitigating effect of market overweighting on analyst underweighting of operating earnings and the details of its cash and accrual components. ${ }^{21}$

Overall, it appears that analysts ignore (or unravel) the overweighting bias in stock prices when making their year $t+1$ forecasting decisions following the release of year $t$ financial statements. Even without controlling for the overweighting bias in stock prices, the evidence in Table 6 suggests that analysts underweight net operating income and all of its free cash-flow and accrual components. Panels A and B show statistically significant underweighting of the persistence of net operating income (Panel A) and its two major components: free cash flow and accruals (Panel B). Panel C shows that analyst underweighting of the sales growth component of earnings drives the underweighting of accruals persistence. Table 4 shows that the persistence of $-\triangle E F F_{t}$ increases with sales growth, and the interaction term in Table 6 Panel $\mathrm{C}$ suggests that analyst underweighting of the one-year-ahead persistence of $-\triangle E F F_{t}$ increases with firms' growth prospects. Apparently, analysts react more conservatively to the future earnings implications of increased investment in net operating assets by rapidly growing firms.

Table 6 Panel D reports results indicating that analysts' year $t+1$ forecasts strongly underweight information in the retained cash and distributions to both debt and stockholder components of free cash-flow persistence. Overall, our results are generally consistent with investor overweighting and analyst underweighting of the persistence of earnings and its free cash-flow and accrual components. Furthermore, we find significant evidence of analysts' biased forecasts mitigating investor overweighting, but very little evidence consistent with biased stock prices mitigating analyst underweighting. ${ }^{22}$

${ }^{21}$ If, instead of decomposing total accruals into efficiency change and sales growth components, we follow Ahmed et al. (2006) and decompose total accruals into working capital and long-term components, we find that, without controls for investor overweighting, analysts' underweight the persistence of long-term accruals but not working capital accruals. After controlling for investor overweighting, we find that analysts underweight persistence of both working capital and long-term accruals. Details of these untabulated results are available from the authors upon request.

${ }^{22}$ We also conduct all tests over two subperiods: pre-Reg FD (1988-1999) and postGlobal Settlement (2004-2011). The results for the pre-Reg FD period are qualitatively similar to the results reported in the tables. The results for the post-Global Settlement period are similar to the pre-Reg FD results except that we cannot reject the hypothesis that the market and analysts with and without the influence of each other respond efficiently to accrual earnings. These results are consistent with Green et al. (2011) who find no evidence of an accrual anomaly during the years following the Global Settlement. 
Our empirical results, suggesting that analysts generally underweight earnings persistence, are consistent with the theory of analyst underweighting developed in Raedy et al. (2006). Raedy et al. (2006) develop a mathematical model predicting generalised analyst underweighting, given an asymmetric loss function that punishes analysts more severely for reversing the direction of their earnings forecasts in the light of new information. This view suggests that analysts are sophisticated users of financial accounting information and, as such, understand the persistence properties of various earnings components. However, economic incentives lead analysts to underweight, and the underweighting is apparent across all cash and accrual components of earnings. On the other hand, the market includes unsophisticated investors, who apparently overweight the persistence of accrual and cash-flow components of earnings, and market frictions prevent sophisticated arbitragers from fully exploiting these inefficiencies.

\section{Summary and conclusions}

This study examines biases in stock prices and financial analysts' earnings forecasts with reference to persistence characteristics of net operating income and its free cash-flow and accrual components. These biases take the form of systematic overweighting or underweighting. We find that stock prices have a general tendency to overweight the persistence of net operating income and its components, whereas financial analysts have a tendency to underweight the same information. Analysts' forecasting bias appears to attenuate what otherwise would appear as more pronounced stock price overweighting. On the other hand, we find little evidence that the bias in stock prices attenuates analyst underweighting.

One explanation for our results is that the strong positive relation between returns on equity securities and revisions in analysts' expectations about firms' future earnings stems from the following: (i) analysts directly accessing information underlying stock price changes (as opposed to indirectly assimilating the information through observation of price changes); and (ii) analysts providing information directly to investors (as opposed to investors directly accessing information underlying changes in analyst expectations). In this manner, biases in analysts' forecasts affect investor decisions and, to some degree, find their way into stock prices, whereas biases in stock prices do not travel back to analysts.

We derive earnings components from disaggregating free cash flows as in Dechow et al. (2008) and from disaggregating accruals as in Richardson et al. (2001, 2006). Both studies begin by disaggregating net operating income into free cash-flow and accrual components. Dechow et al. (2008) further disaggregate free cash flow based on how the firm distributes (funds) a surplus (deficit). These distribution and funding decisions are categorised as changes in cash and net distributions to debtholders and stockholders with the sign of the 
amount in each category depending on whether the amount reflects a distribution or funding decision. Richardson et al. (2001, 2006) disaggregate accruals into those related to sales growth and those related to changes in efficiency (asset turnover).

We find evidence of general analyst underweighting of the persistence of all components of net operating income. Our evidence suggests that the analyst underweighting bias attenuates investor overweighting, resulting in stock prices that show significantly reduced evidence of inefficiency with respect to net operating income as a whole, free cash flow as a whole, accrual earnings as a whole, the detailed cash retention and distribution to investors components of free cash flow, and the detailed sales growth and change in efficiency components of accrual earnings. On the other hand, we find very little evidence of the overweighting bias in stock prices influencing the underweighting bias in analysts' forecasts.

Overall, we find that, left to their own devices, analysts' earnings forecasts underweight the persistence characteristics of annual earnings, and stock prices would overweight, but biased analysts' forecasts largely mitigate this overweighting tendency. This study brings a new perspective to the literature regarding the role of financial analysts in capital markets. Beginning with Abarbanell and Bernard (1992), many studies examine the role of financial analysts in relation to anomalous stock market behaviour. However, these studies invariably look to analysts for root causes of market inefficiency. Instead, we find that analysts play a disciplining role that reins in the tendency for investors and stock prices to overweight information about future earnings. Raedy et al. (2006) provide a theoretical framework within which to study economic incentives behind this disciplining role of financial analysts. We leave further exploration of such economic incentives for future research.

\section{References}

Abarbanell, J., and V. Bernard, 1992, Tests of analysts' overreaction/underweighting of earnings information as an explanation for anomalous stock price behavior, Journal of Finance 47, 1181-1207.

Ahmed, A., K. Nainar, and F. Zhang, 2006, Further evidence on analyst and investor misweighting of prior period cash flows and accruals, The International Journal of Accounting 41, 51-74.

Alford, A., and P. Berger, 1999, A simultaneous equations analysis of forecast accuracy, analyst following, and trading volume, Journal of Accounting, Auditing, and Finance 14, 219-240.

Barth, M., and A. Hutton, 2004, Analysts earnings forecast revisions and the pricing of accruals, Review of Accounting Studies 9, 59-96.

Barth, M. E., D. P. Cram, and K. K. Nelson, 2001, Accruals and the prediction of future cash flows, The Accounting Review 76, 27-58.

Billings, B., and R. Morton, 2001, Book-to-market components, future security returns, and errors in expected future earnings, Journal of Accounting Research 39, 197-220. 
Blouin, J., J. E. Core, and W. Guay, 2010, Have the tax benefits of debt been overestimated?, Journal of Financial Economics 98, 195-213.

Bradshaw, M., and R. Sloan, 2002, GAAP versus the street: an empirical assessment of two alternative definitions of earnings, Journal of Accounting Research 40, 41-66.

Bradshaw, M., S. Richardson, and R. Sloan, 2001, Do analysts and auditors use information in accruals?, Journal of Accounting Research 39, 45-74.

Brown, L., 1993, Earnings forecasting research: its implications for capital markets research, International Journal of Forecasting 9, 295-320.

Brown, P., G. Foster, and E. Noreen, 1985, Security Analyst Multi-Year Earnings Forecasts and the Capital Market No. 21 (American Accounting Association, Sarasota, Florida, USA).

Brown, L., A. Call, M. Clement, and N. Y. Sharp, 2015, Inside the black box of sell side financial analysts, Journal of Accounting Research 53, 1-47.

Chen, J. Z., and P. B. Shane, 2014, Changes in cash: persistence and pricing implications, Journal of Accounting Research 52, 599-634.

Clement, M., J. Hales, and Y. Xue, 2011, Understanding analysts' use of stock returns and other analysts' revisions when forecasting earnings, Journal of Accounting and Economics 51, 279-299.

Collins, D., and P. Hribar, 2000, Earnings-based and accrual-based anomalies: one effect or two?, Journal of Accounting and Economics 29, 101-123.

Collins, D. W., G. Gong, and P. Hribar, 2003, Investor sophistication and the mispricing of accruals, Review of Accounting Studies 8, 251-276.

Cooper, M., H. Gulen, and M. Schill, 2005, What best explains the cross-section of stock returns? Exploring the asset growth effect, Working paper (Purdue University).

Dechow, P., 1994, Accounting earnings and cash flows as measures of firm performance: the role of accounting accruals, Journal of Accounting and Economics 18, 3-42.

Dechow, P., and R. Sloan, 1997, Returns to contrarian investment strategies: tests of naive expectations hypotheses, Journal of Financial Economics 43, 3-27.

Dechow, P., A. Hutton, and R. Sloan, 1999, An empirical assessment of the residual income valuation model, Journal of Accounting and Economics 26, 1-34.

Dechow, P., S. Richardson, and R. Sloan, 2008, The persistence and pricing of the cash component of Earnings, Journal of Accounting Research 46, 537-566.

Desai, H., S. Rajgopal, and V. Venkatachalam, 2004, Value-glamour and accrual mispricing: one anomaly or two?, The Accounting Review 79, 355-385.

Doukas, J., C. Kim, and C. Pantzalis, 2002, A test of the errors-in-expectations explanation of the value/glamour stock returns performance: evidence from analysts' forecasts, Journal of Finance 57, 2143-2165.

Drake, M., and L. Myers, 2011, Analysts' accrual-related over-optimism: do analyst characteristics play a role?, Review of Accounting Studies 16, 59-88.

Elgers, P., and D. Murray, 1992, The relative and complementary performance of analyst and security-price-based measures of expected earnings, Journal of Accounting and Economics 15, 303-316.

Elgers, P., M. Lo, and R. Jr Pfeiffer, 2003, Analysts' vs. investors' weightings of accruals in forecasting annual earnings, Journal of Accounting and Public Policy 22, 255-280.

Fairfield, P., S. Whisenant, and T. Yohn, 2003, Accrued earnings and growth: implications for future profitability and market mispricing, The Accounting Review 78, 353-371.

Frankel, R., S. Kothari, and J. Weber, 2006, Determinants of the informativeness of analyst research, Journal of Accounting and Economics 41, 29-54.

Gleason, C., and C. Lee, 2003, Analyst forecast revisions and market price discovery, The Accounting Review 78, 193-225. 
Green, J., J. Hand, and M. Soliman, 2011, Going, going, gone? The apparent demise of the accruals anomaly, Management Science 57, 797-816.

Gurun, U., R. Johnston, and S. Markov, 2011, Sell-side debt analysts and market efficiency, Working paper (University of Texas at Dallas and Purdue University).

Hanlon, M., 2005, The persistence and pricing of earnings, accruals, and cash flows when firms have large book-tax differences, The Accounting Review 80, 137-166.

Hong, H., T. Lim, and J. Stein, 2000, Bad news travels slowly: size, analyst coverage, and the profitability of momentum strategies, Journal of Finance 55, 265-295.

Hribar, P., and J. McInnis, 2012, Investor sentiment and analysts' earnings forecast errors, Management Science 58, 293-307.

Hribar, P., and N. Yehuda, 2008, Reconciling growth and persistence as explanations for accrual mispricing, Working paper (University of Iowa and Cornell University).

Ikenberry, D., and S. Ramnath, 2002, Underweighting of self-selected news events: the case of stock splits, Review of Financial Studies 15, 489-526.

Jackson, A., and T. Johnson, 2006, Unifying underweighting anomalies, Journal of Business 79, 75-114.

Kadiyala, P., and P. Rau, 2004, Investor reaction to corporate event announcements: underweighting or overreaction?, Journal of Business 77, 357-386.

Kraft, A. G., A. J. Leone, and C. E. Wasley, 2007, Regression-Based tests of the market pricing of accounting numbers: the Mishkin test and ordinary least squares, Journal of Accounting Research 45, 1081-1114.

La Porta, R., 1996, Expectations and the cross-section of stock returns, Journal of Finance 51, 1715-1742.

Louis, H., A. Sun, and O. Urcan, 2013, Do analysts sacrifice forecast accuracy for informativeness?, Management Science 59, 1688-1708.

Mashruwala, C., S. Rajgopal, and T. Shevlin, 2006, Why is the accrual anomaly not arbitraged away? The role of idiosyncratic risk and transactions costs, Journal of Accounting and Economics 13, 341-363.

Mishkin, F., 1983, A Rational Expectations Approach to Macroeconometrics: testing Policy Effectiveness and Efficient-Markets Models (University of Chicago Press for the National Bureau of Economic Research, Chicago, IL).

Purnanandam, A., and B. Swaminathan, 2004, Are IPOs really underpriced?, The Review of Financial Studies 17, 811-848.

Raedy, J., P. Shane, and Y. Yang, 2006, Horizon-dependent underweighting in financial analysts' earnings forecasts, Contemporary Accounting Research 23, 291-322.

Rajan, R., and H. Servaes, 1997, Analyst following of initial public offerings, Journal of Finance 52, 507-529.

Ramnath, S., S. Rock, and P. Shane, 2005, Value Line and I/B/E/S earnings forecasts, International Journal of Forecasting 21, 185-198.

Ramnath, S., S. Rock, and P. Shane, 2008a, A review of research related to financial analysts' forecasts and recommendations, Foundations and Trends in Finance 24, 311-421.

Ramnath, S., S. Rock, and P. Shane, 2008b, Financial analyst forecasting literature: taxonomy with suggestions for further research, International Journal of Forecasting 24, 34-75.

Richardson, S., R. Sloan, M. Soliman, and I. Tuna, 2001, Information in accruals about the quality of earnings, Working paper (University of Michigan).

Richardson, S., R. Sloan, M. Soliman, and I. Tuna, 2005, Accrual reliability, earnings persistence and stock prices, Journal of Accounting and Economics 39, 437-485.

Richardson, S., R. Sloan, M. Soliman, and I. Tuna, 2006, The implications of accounting distortions and growth for accruals and profitability, The Accounting Review 81, 713-743. 
Schipper, K., 1991, Analysts' forecasts, Accounting Horizons 5, 105-121.

Shane, P., and P. Brous, 2001, Investor and (Value Line) analysts underweighting of information about future earnings: the corrective role of non-earnings surprise information, Journal of Accounting Research 39, 351-373.

Sloan, R., 1996, Do stock prices fully reflect information in accrual and cash flows about future earnings?, The Accounting Review 71, 289-315.

So, E. C., 2013, A new approach to predicting analyst forecast errors: do investors overweight analyst forecasts?, Journal of Financial Economics 108, 615-640.

Teoh, S., and T. Wong, 2002, Why new issues and high-accrual firms underperform: the role of analysts' credulity, The Review of Financial Studies 15, 869-900.

Thomas, J. K., and H. Zhang, 2002, Inventory changes and future returns, Review of Accounting Studies 7, 163-187.

Xie, H., 2001, The mispricing of abnormal accruals, The Accounting Review 76, 357-373.

Yu, Y., 2007, How do investors and analysts react to accruals? Evidence from a quarterly analysis, Working paper (University of Texas at Austin).

\section{Appendix}

Variable definitions (firm $i$ subscripts suppressed).

$R E T_{t+1}=$ the annual buy and hold size-adjusted return, calculated by subtracting the value-weighted average return for all firms in the same sizematched decile, where size is measured as market capitalisation at the beginning of the return accumulation period. The return accumulation period begins with the fifth month following the end of fiscal year $t$ and ends with the first trading day following the earnings announcement date of fiscal year $t+1$. Earnings announcement dates come from $\mathrm{I} / \mathrm{B} / \mathrm{E} / \mathrm{S}$.

$F E_{t+1, a}=$ the signed forecast error, calculated as $\left(A_{t+1}-F_{t+1, a}\right) / P_{B}$.

$F E_{t+1, b}=$ the signed forecast error, calculated as $\left(A_{t+1}-F_{t+1, b}\right) / P_{B}$.

$A_{t+1}=$ actual split-adjusted earnings for fiscal year $t+1$, per $\mathrm{I} / \mathrm{B} / \mathrm{E} / \mathrm{S}$.

$F_{t+1, a}=$ the most recent $\mathrm{I} / \mathrm{B} / \mathrm{E} / \mathrm{S}$ individual split-adjusted analyst forecast prior to the beginning of the return accumulation period but after the year $t$ earnings announcement date. When more than one forecast occurs on that day, $F_{t+1, a}$ is the median of those forecasts.

$F_{t+1, b}=$ the first split-adjusted forecast of $t+1$ earnings dated in the fifth month of fiscal year $t+1$. When more than one forecast occurs on that day, $F_{t+1, b}$ is the median of all forecasts occurring on that day.

$P_{B}=$ the split-adjusted price taken from the same $\mathrm{I} / \mathrm{B} / \mathrm{E} / \mathrm{S}$ report month containing $F_{t+1, k}$.

$N O A_{t}=$ total operating assets - total operating liabilities for fiscal year $t$, where cash and investments are defined as financial assets. Equivalently,

$$
N O A_{t}=D E B T_{t}+C S E_{t}-C A S H_{t} .
$$


Compustat variables used to measure $N O A_{t}$ (quotations come from Compustat manuals):

- $D_{E B T_{t}}=D L C_{t}+D L T T_{t}+P S T K_{t}+M I B_{t}$

- $C S E_{t}=C E Q_{t}$

- $\mathrm{CASH}_{t}=\mathrm{CHE}_{t}+\mathrm{IVAO}$

- $C H E=$ cash and short-term investments

- $I V A O=$ investments and advances (other). We assign a value of zero when IVAO is missing from the Compustat database.

- $D L C=$ debt in current liabilities. We assign a value of zero when $D L C$ is missing from the Compustat database.

- $D L T T=$ total long-term debt, that is 'The item represents debt obligations due more than one year from the company's balance sheet date'. We assign a value of zero when DLTT is missing from the Compustat database.

- $P S T K=$ total preferred stock, that is 'This item represents the net number of preferred shares at year-end multiplied by the par or stated value per share as presented in the company's Balance Sheet'.

- $M I B=$ minority interest (Balance Sheet).

- $C E Q=$ total common/ordinary equity. $A C C_{t}=\left(N O A_{t}-N O A_{t-1}\right) / N O A_{t-1}=$ the percentage change in non-cash net operating assets, defined as total operating accruals for fiscal year $t$. See the appendix in Richardson et al. (2006) for a proof of the decomposition of $A C C$ into sales growth and asset efficiency components.

$$
A C C_{t}=S G_{t}-E F F_{t}-S G_{t} * E F F_{t},
$$

where

- $S G_{t}=$ sales growth, calculated as $\left(S A L E_{t} / S A L E_{t-1}\right)-1$

- $\triangle E F F_{t}=$ the deflated change in asset efficiency, calculated as $\left(E F F_{t}-E F F_{t-1}\right) / E F F_{t}$, where $E F F_{t}=S A L E_{t} / N O A_{t}$.

$R N O A_{t}=N O I_{t} / N O A_{t-1}=$ net operating income deflated by $N O A_{t-1}$. $e_{t+1}=$ the portion of $R N O A_{t+1}$ that is not explained by the persistence of the components of $R N O A_{t}$ on the right-hand side of (10).

$N O I=$ Income available to common shareholders + Net financing expense $=I B C O M+\left[(X I N T-I D I T) *\left(1-B C G_{-} M T R I N T\right)+D V P+M I I\right]$,

where

- $I B C O M=$ income before extraordinary items available to common shareholders,

- $X I N T=$ total interest and related expense,

- $I D I T=$ total interest and related income, 
- $B C G_{-} M T R I N T=$ marginal tax rate after interest deductions or postfinancing MTR (Blouin et al., 2010),

- $D V P=$ preferred dividends,

- $M I I=$ non-controlling interest (income statement).

Model (5) defines free cash flow $(F C F)$ as:

$$
F C F=N O I-\triangle N O A=\triangle C A S H+D I S T \_E Q+D I S T \_D,
$$

where $\triangle C A S H$ represents cash retained from (or used in) operations, $D I S T_{-} E Q$ represents cash distributed to (or received from) stockholders, and $D I S T \_D$ represents cash distributed to (or received from) debtholders. Using the Compustat variable definitions above, we measure each term in (5) directly as follows:

- $\triangle C A S H=(\triangle C H E+\triangle I V A O) / N O A_{t-1}$,

- $D I S T_{-} E Q=(I B C O M-\triangle C E Q) / N O A_{t-1}$,

- $D I S T \_D=[N F E-(\triangle D L C+\triangle D L T T+\triangle P S T K+\triangle M I B)] / N O A_{t-1}$,

- $N F E=(X I N T-I D I T)^{*}\left(1-B C G_{-} M T R I N T\right)+D V P+M I I$. 